\title{
A Review on Renewable Energy Systems for Irrigation in Arid and Semi-Arid Regions
}

\author{
Doroteia Hipoldina dos Santos Isaías ${ }^{1}$ Boaventura Chongo Cuamba ${ }^{1,2}$, António José Leão ${ }^{1,2}$ \\ ${ }^{1}$ Faculty of Sciences, Eduardo Mondlane University, Maputo, Mozambique \\ ${ }^{2}$ Energy Research Center, Eduardo Mondlane University, Maputo, Mozambique \\ Email: hipoldina@gmail.com
}

How to cite this paper: dos Santos Isaías, D.H., Cuamba, B.C. and Leão, A.J. (2019) A Review on Renewable Energy Systems for Irrigation in Arid and Semi-Arid Regions. Journal of Power and Energy Engineering, 7, 21-58.

https://doi.org/10.4236/jpee.2019.710002

Received: July 3, 2019

Accepted: October 21, 2019

Published: October 24, 2019

Copyright (c) 2019 by author(s) and Scientific Research Publishing Inc. This work is licensed under the Creative Commons Attribution International License (CC BY 4.0).

http://creativecommons.org/licenses/by/4.0/

\begin{abstract}
The lack of water in arid and semi-arid regions has often limited agricultural production. Indeed, even where water is available for irrigation, the lack of electricity, as well as the high costs of diesel, has created constraints on small farmers. The purpose of this research is to review the renewable energy potential available in arid and semi-arid zones that can be used for irrigation as a substitute for fossil fuels. In this review, the solar thermal irrigation, solar photovoltaic (PV) irrigation, wind pumping and biomass pumping are discussed. The comparison of different hybrid pumping systems and analyses of renewable sources irrigation assessment in arid and semi-arid regions of Mozambique also are discussed. The results of this study showed that there are still certain technological limitations regarding the use of solar thermal energy for irrigation. As far as wind power is concerned, the analysis of the pumping water life cycle cost showed that the wind power water pumping system is more economical and viable compared to the diesel based system. However, the study concluded that photovoltaic solar energy has been shown to be more viable for pumping water for irrigation in arid and semi-arid regions.
\end{abstract}

\section{Keywords}

Renewable Energy Systems, Water Pumping, Irrigation,

Arid and Semi-Arid Regions

\section{Introduction}

The agriculture sector, like other sectors, has become increasingly dependent on energy resources [1] and this is a major consumer in many countries of the world [2]. This dependence is caused in part by the modernization of many 
agricultural production operations, such as irrigation, among others. Globally, electric irrigation pumps consume around 62 terawatt-hours per annum [3]. The main function of irrigation is to provide controlled water for crops where rainfall is not sufficient to meet the evapotranspiration demand of the atmosphere, and in turn, water can be extracted from surface reservoirs or aquifers. However, the arid and semiarid regions have been confronted with a lack of water, thus limiting, among several activities, the irrigation of crops [4] [5]. It's because, normally these regions are most affected by droughts and wide climatic variability, which, when combined with population growth and economic development, make water scarcity problems more acute [6]. In the meantime, even if farmers have water to irrigate crops, it is necessary that they have the energy to transport the water from the storage point to the agricultural field. Unfortunately, it is a fact that farmers in the arid and semi-arid areas, in addition to suffering from a lack of water, are also lacking energy for irrigation. Indeed, even if farmers increase their access to modern energy for pumping through grid electricity or diesel fuel, a large proportion continues to rely on seasonal rains for irrigation. Thus, in this non-access context, farmers are expected to invest in pumping systems to obtain access to groundwater or surface water [3].

Diesel, gasoline and kerosene pumps (including windmills) have traditionally been used to pump water [7] [8], diesel being the most widely used fuel for crop irrigation. However, reliability and availability problems may exist in places where fuel supply is erratic and costly, coupled with the high cost of maintaining the pump as well as the lifetime useful [9]. Therefore, fuel-based solutions are not ideal, especially in remote areas where the cost of transportation can be inhibitive [3]. Fortunately, there are other sources of energy, such as wind, solar and biomass, which are available in unlimited quantities [2]. Renewable energy sources have received much attention as a substitute for fossil fuels or as a supplement in hybrid systems [9], these sources are particularly useful remote sites where a constant supply of fuel is a problematic and qualified maintenance staff is scarce [8]. Hence, to sustain agricultural production, efficient use of energy is necessary as it provides financial savings, preservation of fossil resources and reduction of air pollution [1]. Several studies referring to the review of water pumping systems have already been carried out by several authors [9]-[13]. However, few authors focus on irrigation in arid and semi-arid regions and mainly in the African context. The present study has some contribution regarding irrigation mainly in arid and semi-arid zones. Therefore, this research aims at reviewing the renewable energy systems for small-scale irrigation in the semi-arid regions; and for such, a summary of various studies on pumping systems using renewable sources are presented and discussed.

The focus of this research is to review the renewable energy potentialities available in arid and semi-arid regions that can be used for irrigation to replace fossil fuels. However, natural geography in arid and semi-arid zones is complex and varies from place to place, but there are characteristics that are common such as irregular rains, extreme drought, poor vegetation cover, low coverage, 
erosion and high concentrations of sediment during the rainy season. Among these characteristics, precipitation, which is the source of surface water and groundwater, constitutes the main hydrological variable within arid and semi-arid zones and this varies significantly from place to place [14]. Thus, results of this study could be modeled for any semi-arid region, since these zones generally have the same characteristics.

\section{Review on Solar Thermal Irrigation}

A solar pump is powered by solar energy, either directly by converting the solar resource into electricity or indirectly by using solar-thermal heat collectors. Delivering solar energy irrigation systems is reliable and environmentally sustainable in a growing number of contexts. Solar-based irrigation systems can be dimensioned to meet the diverse demands of energy and contribute to a dissociation of growth in irrigated areas from the use of fossil fuels, improving livelihoods [3]. The great optimism surrounding solar-powered devices, particularly pumps, has been whittled away as the magnitude of the technical task became better appreciated. With solar energy, there are diurnal and seasonal variations which are predictable, and then essentially random variations due to cloud cover. These must be added to all the normal problems encountered in power conversion systems. Furthermore, solar powered plant will almost always be located in remote areas where land costs are less, and where communication and transport problems make fuelled systems less economical [15]. In this section will be presented the authors' summary review in terms of solar thermal pumping system and also solar thermal pumping performance.

\subsection{Solar Thermal Pumping System}

In most systems, solar energy is used to heat a medium (liquid or gas), which transfers thermal energy to a motor (it can be a turbine, a steam engine or a Stirling engine) [16]. The solar thermal water pumping system works on the principle of a closed "Rankine cycle" [17]. The boiler containing the working fluid receives solar heat and generates high-pressure vapour. This vapour enters into a reciprocating double acting piston type expander, which generates mechanical power. The schematic of Rankine cycle solar water pump is shown in Figure 1 .

The solar thermal water pumps are low cost and low maintenance devices with a pumping capacity of $0.2-1 \mathrm{~m}^{3}$ /hour at a dynamic head of $1.5-5 \mathrm{~m}$ [18].

In Arab countries, Al-Sakaf [19] studied the possibility of applying solar thermal power plants. According to the author, these countries are best suited for the use of solar thermal power plants, and their use would bring the Arab countries many advantages, especially, through the substitution of environment threatening and damaging emissions of conventional energy sources being currently in use for electricity generation. 


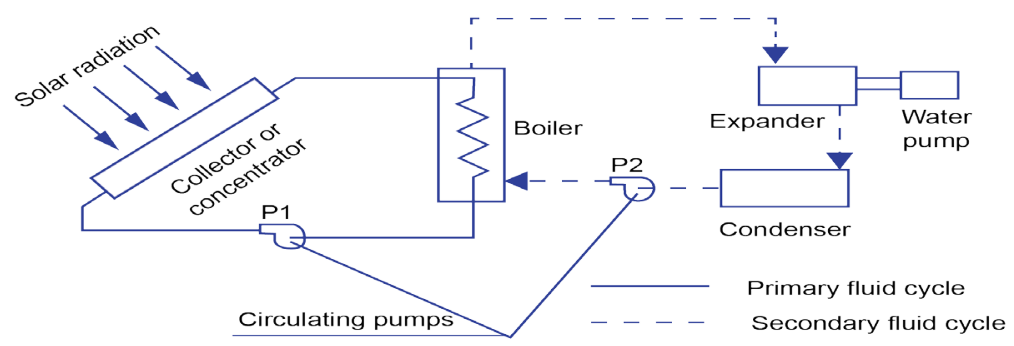

Figure 1. The schematic of Rankine cycle solar water pump [13].

Wong and Sumathy [13] reviewed solar thermal water pumping systems. In this review, they discussed the two main kinds of solar thermal water pumping systems (conventional and unconventional). Authors referred that unconventional types are relatively simple. Furthermore, despite of the lower efficiency, these pumps are attractive to users since solar energy is abundantly available. According to them, one of the limitations of solar thermal water pumping system is their bulk and relatively low pumping head.

\subsection{Solar Thermal Pumping Performance}

Ahmadia et al. [20] reviewed thermal models for analysis of the performance of Stirling engine. According to Wazed et al. [10], the most effective solar thermal system utilizes a solar concentrator powering a Stirling pump, there is no energy storage but instead the system functions at optimal sun hours and stores water. Sumathy et al. [21] analyzed the principle of the workings of a solar thermal water pump with n-pentane as the working fluid. In this study, the performance of the pump is predicted from the thermodynamic analysis of the cycle of events. Wong and Sumathy [22] concluded that the performance of the solar thermal water pump depends mainly on heating time and condensation time, and also, in order to achieve a continuous operation of the pump (to an extent possible), the heating time and condensation time should be shorter than the pumping time. The authors identified that the initial amount of ethyl ether controls the heating time and the preferred condensation time can be obtained by optimizing the surface area of cooling coil.

Bataineh [23] investigated the performance of solar thermal system for powering irrigation pump. The author also summarized the recent developments of solar thermal power systems. Furthermore, it updates the literature about the recent findings of thermal solar power system and presents different methodologies of enhancing the solar energy conversion system. The results showed that the daily average overall system efficiency ranges between $10 \%$ and $13 \%$; and simulation results showed that there is an optimal steam mass flow rate where optimal efficiency can reach around $18 \%$. Also, the results showed that the concentration ratio has negligible effect on the overall system efficiency. The study found that using Parabolic Trough Collector (PTC) of collecting area of $526 \mathrm{~m}^{2}$ can produce above $30 \mathrm{~kW}$ of power using Steam Rankine Cycle (SRC). The value of solar energy cost was obtained as $\$ 0.075 / \mathrm{kWh}$ using $526 \mathrm{~m}^{2}$ of collector area 
which is less than energy cost by diesel engine pump.

Baral et al. [24] performed the experimental and thermo-economic analysis of Small-Scale Solar Organic Rankine Cycle (SORC) System. The experimental results showed acceptable performance characteristics that could be suitable for installation in rural areas. The maximum solar ORC efficiency was found to be approximately $6 \%$ for a $120^{\circ} \mathrm{C}$ solar source temperature. Equally, the study showed that the selling price of electricity (for prototype) was $\$ 0.68 / \mathrm{kWh}$, whereas for low cost solar ORC was $\$ 0.39 / \mathrm{kWh}$. The payback period for the solar ORC system is 19 years, which is almost equal to life cycle of the system. Since the payback period is very high, the authors recommend that this technology be used only in rural areas of developing countries, which lack electricity for lighting homes.

Bandaru et al. [25] developed a mathematic model to simulate the solar-thermal energy conversion and consequent change in the properties of working fluid in an unconventional solar thermal water pump with flat plate collector. Likewise, Mahkamov and Orda [18] developed a simplified mathematical model for the simulation of the working process of solar thermal water pumps. The results of the analysis showed that the performance of the solar water pump is mainly determined by the performance of the steam part of the combined air-steam cycle. Moreover, the power of the solar thermal water pump increases with an increase in the maximum temperature in the cycle, whilst the indicated efficiency reduces because of the increase in the heat loss due to water vaporization and condensation processes.

Kokila and Rajakumar [26] analyzed the thermal performance of direct expansion solar assisted heat pump DX-SAHP (A) by numerical simulation in MATLAB and compared it with the thermal performance of DX-SAHP (B) which has an optimized collector area and mass flow rate. From the experiment results, the authors concluded that the performance of the optimized system has a maximum Coefficient Of Performance (COP) of 6.85 which is greater that of DX-SAHP (A) with COP of 5.2. The final water temperature can be obtained 100 minutes earlier in the optimized system DX-SAHP (B) with compressor work less than that of system A. The results showed that the optimized DX-SAHP (B) water heating system has a better performance.

Kurhe et al. [27] presented the description and operation of solar powered heat engine for water pumping operation. The design of the heat engine was based on thermal water pump cycle and uses organic working fluid. According to the authors, the heat engine model was developed to deliver $2 \mathrm{~L}$ per stroke and at operating head of $5 \mathrm{~m}$. The system showed efficiency in the range of $0.25 \%$ - $0.5 \%$ and the main cause for the limited efficiency is loss of heat through the membrane which is present at the interface water.

Studies refer that the operation of a small solar pump for 6 hours/day implies around $20 \mathrm{~m}^{3}$ over ahead of $3.5 \mathrm{~m}$, which would amount to $2 \mathrm{~mm}$ of water on 1 hectare of land or $6 \mathrm{~mm}$ on $1 / 3$ of a hectare. Thus, the overall efficiency of the small solar pump is around $2 \%$ to $2.5 \%$ (hydraulic output/solar insolation) [17]. 
Delgado-Torres concluded that conventional systems are low power output and low efficiency systems, this means that below $20 \mathrm{~kW}$ with the exception of the $150 \mathrm{~kW}$ solar Coolidge irrigation plant and below 5\% respectively. In sum, Rankine Cycle with water or an organic substance as working fluid is used as power cycle to convert solar thermal energy into work [28].

Sitranon et al. [29] conducted a study aimed at improving the performance of solar thermal water heater on the roofs of buildings. The heat pump was introduced with the aim of reducing the weight on the roofs of buildings and saving electricity in the water circulation, but the efficiency was not enough. In order to improve performance, a new $1.58 \mathrm{~m}^{2}$ flat plate solar collector system, an air tank placed at the peak level, a larger water storage tank without a heat exchanger at the lower level, a new ventilation tube and a one-way valve for water circulation control were built. The discharge head has been reduced to $0.5 \mathrm{~m}$. A pump was steam-fed and operated at a solar collector temperature of about $70^{\circ} \mathrm{C}-80.2^{\circ} \mathrm{C}$ and gauge pressure of $2.2-6.3 \mathrm{kPa}$. The stored hot water from the solar water heater ranged from 25 to $89.9 \mathrm{~L}$ per day. In addition, the maximum water temperature in the storage tank was approximately $64.6^{\circ} \mathrm{C}$. The maximum daily efficiency of the pump was about $0.0012 \%$. For the discharge head of $0.5 \mathrm{~m} \mathrm{~h}$, the maximum daily thermal efficiency of the solar water heater was about $41.2 \%$ compared to $17.4 \%$ for a prior system of the same type. The simulation of the system gave a reasonable agreement with the experimental results (error less than $10 \%)$. In addition, this system also reduces the discharge head, making the pump cycle period faster.

Spindler et al. [30] tested a small solar thermal water pump prototype, described the pump design and also detailed the performance of temperature and pressure measurements of the working fluid for different operating conditions. The results showed that the temperature and pressure distribution levels of the working fluid for different water temperatures at constant pumping head of 3.2 $\mathrm{m}$ and electrical input of $2570 \mathrm{~W}$ increase with rising water temperature.

\section{Review on Solar PV Irrigation}

PV technology converts the sun's energy into electricity through electromagnetic means when the photovoltaic module is exposed to sunlight. PV is especially suitable for pumping water because the energy does not need to be stored for night pumping. Instead, water can be stored to provide water overnight [8]. In this section, we review the literature regarding the PV pumping system as well as the performance of these systems.

\subsection{Solar PV Pumping System}

In order to design a PV system, it is necessary to know the availability and accuracy of solar radiation data, however, accurate solar radiation data are rarely available from remote locations where many PV systems are to be installed [8]. Figure 2 shows a schematic diagram of a generalized solar powered water pumping system. 


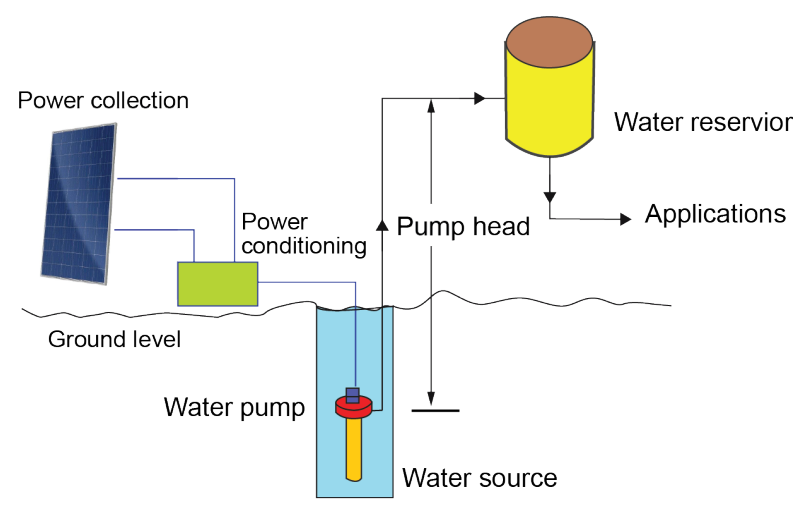

Figure 2. A schematic diagram of a generalized solar PV powered water pumping system [9].

Closas and Rap [31] in their article on sustainability, policies, and limitations in the solar pumping of groundwater for irrigation, highlight the importance of the need to monitor groundwater abstraction, aiming at subsidies and improving knowledge and monitoring of resource use. According to them, failure to address these issues could lead to further depletion of groundwater, which could threaten the sustainability of this technology and dependent livelihoods in the future. Similarly, Maurya et al. [32] discussed the scope and limitations of PV solar water pumping system. According to them, the maintenance is practically zero, has a long service life, do not require fuel, do not contaminate and is straightforward to install. Also, as these use the sun as their energy source, the periods of maximum demand for water coincide with the periods of maximum solar radiation. These pumps are available to pump from anywhere in the range of up to $200 \mathrm{~m}$ head and with outputs of up to $250 \mathrm{~m}^{3} /$ day. In addition, Sontake and Kalamkar [33] discussed the general classification of solar PV water pumping system, historical background of solar pumping systems, the various efforts undertaken by researchers working on the different aspects of solar PV water pumping and the present status of research on the topic. The authors also reviewed maximum power point tracking system, different types of pumps and motors and rating of photovoltaic panel, which affect the performance, efficiency and economy of the solar PV water pumping system.

Results from several studies indicate that the PV pumping system is more economic than diesel powered systems. In Africa, Wazeda et al. [10] reviewed sustainable irrigation systems. They suggested that the best way to optimize the cost and design of the PV power system is to understand the crop requirements and conduct extensive on-site research to analyze the working conditions of the system. This was seen in relation to the use of a battery system where cost savings have been achieved in scenarios without using the battery, while in other applications it has been found that a battery actually reduces costs. While the cost of the PV system over its useful life is much lower compared to diesel-powered systems, the initial investment cost is much higher and especially for small rural farmers. Then, if the purpose of the solar panels is to reduce the 
impact on the environment, it falls short because of a substantial carbon footprint due to the manufacturing impacts and transportation of the technology.

Another study [34], also concluded that PV systems when compared to diesel-powered systems, the cost of the PV pumping system, without any subsidy, amounts to $64.2 \%$ of the cost of the diesel pump, over a cycle of ten years of life. In general, PV pumps are economical compared to diesel pumps up to approximately $3 \mathrm{kWp}$ for village water supply and about $1 \mathrm{kWp}$ for irrigation. PV solar arrays represent an environmentally friendly, low maintenance and economical alternative to irrigation pump assemblies that run on electricity or diesel. According to the study, it is estimated that in India the potential for pumping water for irrigation using solar photovoltaic energy is from 9 to 70 million sets of solar PV pumps, that is, at least 255 billion liters/year of diesel economy. For this reason, in rural areas where diesel fuel is expensive or where reliable access to the electricity grid is lacking, the farmers can provide a relatively flexible and climate friendly alternative energy source. Solar PV irrigation system can be used in large-scale irrigation systems as well as for decentralized, small-scale irrigation [35].

The same results were presented by Eker [36] and Moeeni and Alam [37]. The results indicated that $\mathrm{PV}$ power is more cost competitive when the irrigation system with which it operates has a low total dynamic head. That's why PV power is more cost-competitive when used to power a micro irrigation system as compared to an overhead sprinkler system. Also, PV power for irrigation is cost-competitive with traditional energy sources for small, remote applications, if the total system design and utilization timing are carefully considered and organized to use the solar energy as efficiently as possible [36]. Other research, cited that PV systems for irrigation have the advantage of practically no maintenance when compared to manual pumps or internal combustion, are easy to install and do not contaminate the environment. The authors also estimate that India's potential for PV solar pump assemblies can save at least 255 billion liters of diesel. According to them, the automated drip irrigation system represents a sustainable solution to reduce labor-needed to flood irrigation. The use of this photo-irrigation system may contribute to socio-economic development [37].

In the rural Sudano-Sahel region of West Africa, Burney et al. [38] analyzed solar-powered drip irrigation as a strategy for enhancing food security. Using a matched-pair comparison of villages in northern Benin (two treatment villages, two comparison villages), and household survey and field-level data through the first year of harvest in those villages, the authors find that solar-powered drip irrigation significantly augments both household income and nutritional intake, particularly during the dry season, and is cost effective compared to alternative technologies.

Narale et al. [39] studied the PV solar pumping system in banana irrigation, where they designed the system and made the economic analysis of the efficiency of the PV system. The system under study was designed and installed at Jain 
Irrigation System Limited in Jalgaon (Maharashtra) at $21^{\circ} 05^{\prime} \mathrm{N}$-latitude, $75^{\circ} 40^{\prime} \mathrm{E}$ longitude and at an altitude of $209 \mathrm{~m}$ above average sea level. In this project, the PV design was done in order to irrigate a banana plot of 0.165 ha, with a daily water demand of $9.72 \mathrm{~m}^{3}$ and a total head of $26 \mathrm{~m}$. In addition, to evaluate the economic viability of the system, life cycle cost analysis was performed. The results showed that the system installed irrigates the desired plot ( $0.165 \mathrm{ha})$ in 6.02 $\mathrm{h}$ and also showed that irrigation of orchards in the more remote areas using photovoltaic systems is beneficial and adequate for long-term investments compared to diesel engines, considering the total cost of the PV system and the longevity of 20 years. As for the analysis of the life cycle cost that counted on the two systems (PV and diesel), proved that the PV system is the most economical option when compared to the diesel system.

The procedure to elaborate a computer program, photo-irrigation, to correctly and straight forwardly design a PV installation to power an irrigation pumping system for a given crop at a given site was described by Cuadros et al. [40]. Dursun and Ozden [41] designed an automatic drip irrigation of dwarf cherry trees system with solar powered Brushless DC Motors, in Zile District of Tokat Province of Turkey. The results showed that the use of this photo-irrigation system will be able to contribute to the socio-economic development in the Tokat region.

Kyi et al. [42] studied the solar PV sizing of water pumping system for irrigation of Asparagus. In this study, the authors considered low cost, reliability, alternate source of electric power and automatic control. In Chile, Guzmán et al. [43] studied a cost-effective methodology for the sizing of solar PV systems for existing irrigation facilities, in an effort to improve the competitiveness of the fresh-fruit industry. Martins et al. [44] with the aim of proposing the implantation of an irrigation system with rainwater and PV pumping used Rippl method for the sizing of the cistern. The results showed that this system could bring energy savings of $120.15 \mathrm{kWh} /$ month and a reduction of well water of approximately $20 \mathrm{~m}^{3} /$ month during the 4 months in the year of low precipitation.

Rawat et al. [45] reviewed modeling, design methodology and size optimization of PV based water pumping, standalone and grid connected system. In this paper, a comprehensive review of a comprehensive designing process of solar PV water pumping system, standalone PV system and grid connected PV system was presented.

In Ethiopia, Zegeye et al. [46] carried out the economic design of the PV water pumping system for small-scale irrigation. An analysis was made of the need for electric power to feed the irrigation pumps, where the optimum angle of inclination of the solar panel that can collect the maximum solar energy was determined when the irrigation demand is higher based on the seasonal variation. Likewise, the water requirement for irrigation was determined and the maximum power was minimized in order to select the power that can satisfy all the irrigation periods with reduced cost of the PV system. The authors concluded that the optimization of a PV pumping system for irrigation is possible if there 
are good water distribution policies for irrigation.

$\mathrm{Yu}$ et al. [47] in order to provide solutions for pasture conservation in arid lands in China, carried out a study to evaluate the potential of the solar irrigation system in order to sustain pasture lands. In their study, the researchers took into account the main factors in the study of water resources, including precipitation and groundwater, to analyze the feasibility of using the PV pumping system in irrigation. The results show that pastures suitable for PV pumping are around 8.145 million hectares, accounting for $22.3 \%$ of pastures throughout the province. They also state that the most suitable areas for irrigation using PV solar pumping should be those with annual rainfall ranging from $300-400 \mathrm{~mm}$ considering both the benefit of pumping irrigation of solar energy as well as the sustainability of groundwater.

Campana et al. [48] investigated the geospatial distribution of grazing sites technically suitable for the implementation of PV water pumping systems for irrigation in China. This assessment was conducted using a spatially explicit optimization model of renewable energy systems based on the cost minimization of the entire feed supply chain. The results indicated that the pumping systems of PV water offer high potential to improve forage productivity, contributing to the local demand. According to the authors, ideal locations are highly sensitive to several environmental and economic parameters such as increased forage yield potential, forage management costs, forage water requirements, groundwater depth, forage price and $\mathrm{CO}_{2}$ price.

Schmittera et al. [49] studied the adequacy of the mapping structure for PV solar pumps to be applied to small farmers in sub-Saharan Africa. A multi-criteria model was developed to evaluate the geospatial suitability of two solar PV pumps selected for use in shallow groundwater or surface waters. The technical requirements of small solar pump technology were combined with pre-processed spatial maps. The adequacy analysis was performed through three main steps, where the first consisted of excluding areas that are not suitable for solar application; the second one in reclassification to appropriate classes for each factor and the last one consisted in classifying and weighting of pairs of notes reclassified in input maps. In total, four scenarios were established to assess the suitability of the two selected solar water lifting devices. Of the four scenarios, two represented only groundwater, only one for surface waters and two scenarios combined both water and groundwater: scenario 1 included groundwater depths of up to $25 \mathrm{~m}$ divided into two classes $(0-7 \mathrm{~m}, 7.1$ - $25 \mathrm{~m})$; scenario 2 considered very shallow groundwater levels $(0$ to $7 \mathrm{~m})$; Scenario 3 only responsible for the proximity of rivers or small reservoirs; and scenario 4 combined both water resources (i.e., groundwater up to $25 \mathrm{~m}$ and surface water). The adequacy results following the groundwater scenarios showed good agreement with the depth data. Comparison of adequacy maps with land use data showed that on average $9 \%$ of Ethiopian irrigated and $18 \%$ of rainfed land would be adequate for the use of solar PV irrigation technology.

Based on the analysis of the dynamic variation of the water table, Gao et al. 
[50], evaluated the viability of the solar pumping irrigation system. The study was carried out in the Autonomous Prefecture of Golog in the southern part of the province of Qinghai and counted on an area of 3.15 ha. In order to reach the objective, it was first made the forecast of the demand of grazing water taking into account the hydrological level for different years in order to determine the water deficiency that needs to be replenished. Then, through the modeling, the groundwater change of the pumping well was analyzed in both irrigation and non-irrigation periods, and it was then assessed whether or not groundwater resources could satisfy the demand for pasture growth. The results showed that the groundwater resources in the demonstration area are satisfactory and the water pumping efficiency in the well can generally satisfy the water demand of the pastures. The authors also concluded that the PV system has good economic conditions and good ecological performance at the demonstration site compared to the diesel engine irrigation system.

In Bangladeshi, Islam et al. [51] studied the feasibility of PV grid system for $500 \mathrm{~kW}$ generation plant for irrigation purposes at a semi-arid region of Bangladesh. For this purpose, they used HOMER and RET Screen computer tools and monthly average solar radiation data from NASA. They observed that the per unit electricity production cost from the studied system is cost competitive with grid-connected diesel power generation which is around 15 - 18 BDT (Bangladeshi Taka). In the Algerian Sahara Regions, Bouzidi [52] studied the viability of solar for water pumping systems. The results showed that the cost per cubic meter of water produced by the wind pump system is cheaper than that produced by the PV system.

Vick and Clark [53] analyzed the diaphragm and helical solar PV powered water pumping systems. Data were collected on diaphragm and helical pumps which were powered by different solar PV arrays at multiple pumping depths to determine the pumping performance, efficiency, and reliability of the different systems. The authors could see that, the highest diaphragm pump hydraulic efficiency measured was about $48 \%$, and the highest helical pump hydraulic efficiency measured was about $60 \%$. The peak total system efficiency measured for the diaphragm and helical pumps were around 5\% and around 7\%, respectively. The use of a controller, in this study, was shown to improve the quad diaphragm pump performance below a solar irradiance of $600 \mathrm{~W} / \mathrm{m}^{2}$ (20m head) to 800 $\mathrm{W} / \mathrm{m}^{2}$ (30 $\mathrm{m}$ head). While diaphragm pumps made mostly of plastic demonstrated similar to much better pumping performance than diaphragm pumps made with a high proportion of metal, the metal pumps demonstrated a longer service life (more than 2 years) than the plastic pumps service life (less than 2 years).

In design of a photovoltaic pumping system is only important to take account on average daily, monthly or yearly basis as instantaneous deviations are compensated by water storage. In this way, is possible to obtain more accurate results and also is more practical to use average efficiencies and average performance ratios rather than instantaneous efficiencies when designing or rating PV water 
pumping systems [54].

Carrillo-Cobo et al. [55] evaluating the potential of solar energy in pressurized irrigation, with a case study in the district of Bembézar MI (Spain), developed a new methodology that combined sectorization as a measure of energy and solar energy saving, thus reducing energy requirements and dependence on conventional energy resources. The results showed that this measure could reduce the annual energy bill by $30.4 \%$ without large investments. However, conventional energy would be needed when solar energy was unavailable or insufficient to supply the required flows. These measures together would reduce energy costs by $71.7 \%$ and the greenhouse gas emissions by $70.5 \%$.

Studies state that the use of solar generators (PV arrays) to run water pumps, especially in sunny and developing countries, is very promising. The efficiency of $\mathrm{PV}$ modules is about $15 \%$, the motor-pump subsystem efficiency is $40 \%$ $60 \%$, and inverters are about $95 \%$. The overall efficiency of a PV pump is $6.5 \%$ $9 \%[8]$.

\subsection{Solar PV Pumping Performance}

Atlama and Kolhe [56] analyzed the operation of directly PV powered DC permanent magnet motor e propeller system for selection of motor parameters. The performance of such system mainly depends on the incident solar radiation, operating cell temperature, DC motor and propeller load parameters. Kolhe et al. [57] also analyzed the performance of a PV-powered dc permanent-magnet motor coupled with a centrifugal pump, at different solar intensities and corresponding cell temperature; and it was observed that this system has a good match between the PV array and the electromechanical system characteristics. Additionally, Arab et al. [58] analyzed the performance of different PV water pumping. The research was carried out for three different profiles, three tank capacities, two PV modules types, two PV array configurations and several pumping heads, applied to two centrifugal pumps.

In India, Lal et al. [59] analyzed the performance of PV based submersible water pump. A $2 \mathrm{hp} \mathrm{DC}$ motor with $2200 \mathrm{~W}$ was used for discharge $30 \mathrm{~m}$ water head. The maximum discharge logged $163 \mathrm{~L} /$ minute between $11 \mathrm{AM}$ to $2 \mathrm{PM}$ at PV power output between 75 to $85 \mathrm{~W} / \mathrm{m}^{2}$ and the system was operating approximately 8 hours in the of November of the winter season. The results showed that the full day discharge has found $70,995 \mathrm{~L}$ and according to authors, it is more than the average discharge given by the manufacturer at $50 \mathrm{~m}$ depth. Therefore, it is concluded that PV array based water pumping system is suitable and easible option for off-grid and drip irrigation system.

Reca et al. [60] analyzed the profitability of an autonomous direct PV pumping system for irrigation of Mediterranean greenhouses. For this purpose, a simulation model of the system was developed with the objective of obtaining the ideal economic project and evaluating its feasibility. The proposed model was composed of several sub-models, namely: the PV power generation sub-model, the pumping management sub-model and the sub-model that evaluates the irri- 
gation water requirements for a representative greenhouse and the overall economic performance of the system. The total number of irrigation sectors per hectare was also analyzed. The authors considered two management strategies: irrigation with only one sector or irrigation with a variable number of sectors depending on the input power provided by the PV panel. As a result, the authors stated that the system becomes profitable for at least 4 sectors per hectare. According to them, the profitability and energy efficiency of such systems are relatively low, although these values could be improved if excess energy were used for other purposes such as ventilation or cooling of the greenhouse.

Ghoneim [61] presented the results of performance optimization of a PV powered water pumping system in the Kuwait climate. The direct coupled photovoltaic water pumping system studied consisted of the PV array, DC motor, centrifugal pump, a storage tank that serves a similar purpose to battery storage and a maximum power point tracker to improve the efficiency of the system.

Elkholy and Fathy [62] presented an optimal performance of water pump induction motor connected directly to PV array via three level inverter without storage system. According to the authors, the optimal performance is achieved by controlling the inverter voltage and frequency to obtain maximum power from PV with minimum motor losses using Teaching Learning Based Optimization technique.

Mokeddem et al. [63] investigated the performance of a directly coupled water pumping PV system. The system under study consisted of a $1.5 \mathrm{kWp}$ PV system, DC engine and centrifugal pump. The experiment was conducted over a period of 4 months and the system performance was monitored under different climatic conditions and the solar irradiance was varied with two static head configurations. The authors report that although the pump motor efficiency did not exceed $30 \%$, which is typical for directly coupled PV pumping systems, such a system is clearly suitable for low head irrigation in remote areas not connected to the national grid and where access to water emerges as a priority issue than access to technology. The system works without battery and complex electronic control, therefore, not only the initial cost is low, but also the maintenance, repair and replacement cost can be saved. The study showed that the directly coupled system reaches steady state soon after any abrupt change.

Alghuwainem [64] in "performance analysis of a PV powered dc motor driving a 3-phase self-excited induction generator", used a PV powered dc motor to drive an isolated three-phase self-excited induction generator.

Tiwari and Kalamkar [65] investigated the performance of solar water pumping system using helical pump under the outdoor condition of Nagpur, India. They intended to determine an optimum PV array configuration to supply an adequate amount of energy to a DC Helical pump. Four different PV array configurations have been taken into consideration $(\mathrm{C} 1, \mathrm{C} 2, \mathrm{C} 3 \mathrm{e} \mathrm{C} 4)$. The tests have been carried out for a head of 7 bar, under sunny daylight hours, at the outdoor location of VNIT, college campus Nagpur. The results showed that the configuration (C2) with $20 \%$ lesser PV panel size gives the maximum average system ef- 
ficiency, so this is the best configuration among all the configurations. From this study, it was concluded that PV array configuration is one of the important parameter for solar PV water pumping systems. The PV array configuration needs to be optimized in order to increase the overall efficiency and decrease the cost of the solar PV water pumping system. On the other hand, in Saudi Arabia, Benghanem et al. [66] determined an optimum photovoltaic array configuration, adequate to supply a DC Helical pump with an optimum energy amount, under the outdoor conditions of Madinah site. They used four different PV array configurations to tests and these tests had been carried for a head of $80 \mathrm{~m}$, under sunny daylight hours, in a real well at a farm same local.

Several models with respect to the performance of PV pumping systems have been proposed. A method for estimating the long-term performance of direct-coupled PV pumping systems was developed by Kou et al. [67]. This method uses only information available from the PV module and pump-motor manufacturers and predicts monthly pumped water to within $6 \%$ of TRNSYS predictions based on hourly weather data. Hamidat et al. [68] proposed a mathematical model that directly links the operating electric power to the pump's output water flow rate. The tested pumping system used a submersible motor-pump and an electronic controller DC/DC. The nominal power of the DC motor was $400 \mathrm{~W}$ and the hydraulic system was a positive displacement pump. The pumping performance was determined versus the water consumption profile, the tank capacity, the total head and the peak power of the PV array.

Jones et al. [69] developed models to evaluate PV pumping and desalination system performance without energy storage systems. Simulations were performed under various environmental conditions in order to determine the optimal inverter configuration, membrane type, desalination system configuration and power supply for different scenarios. Results showed that the cost of PV-powered water pumping and desalination was greatly reduced compared to previous research due to the use of larger system sizes, system optimization, and low-energy membranes. Additionally, photovoltaic powered systems were found to be more economical than diesel powered systems, but less economical than grid-powered systems in most cases based on assumed electrical costs. According to the authors, the use of PV water pumping and desalination for agriculture was found to be profitable only for crops with high returns, fairly low water requirements, and locations with shallow groundwater depths, low salinity feed water and high solar insolation.

Picazo et al. [70] proposed a new methodology to select a scheduled program for irrigation which minimizes the number of photovoltaic solar panels to be installed and which better fits energy consumption to available energy obtained by panels without any power conditioning unit.

In St. Catherine area, Egypt, Gad [71] developed a methodology for performance perdition of a proposed direct coupled PV water pumping system. The system consisted of a four modules PV array, with $72 \mathrm{PV}$ cells in each module, pump controller and a 12 VDC submerged pump. The target of the system was 
to supply at least $8 \mathrm{~m}^{3}$ from the well at a total head of $30-40 \mathrm{~m}$. The computer simulation program developed to predict the performance of the proposed system, used models for solar radiation data, the PV array with intermittent tracking and the pump. Results showed that the system was capable of pumping 24.06, 21.47 and $12.12 \mathrm{~m}^{3} /$ day in the summer solstice, equinoxes and winter clear sky days respectively. The calculated PV array efficiency ranged from $13.86 \%$ in winter to $13.91 \%$ in summer solstice which is larger than that specified by the tender (13\%).

Pande et al. [72] designed and developed a solar PV pump operated drip irrigation system for growing orchards in arid region. In their approach, the authors included different design parameters like pumps size, water requirements, the diurnal variation in the pressure of the pump due to change in irradiance and pressure compensation in the drippers.

Zhang et al. [73], in "Economic performance of PV water pumping systems with business model innovation in China", studied the added value of the PV water pumping technologies with an emphasis on the integration of the value proposition with the operation system and customer segmentation. Using the widely used existing PV business models (PV-roof) as a reference, they evaluated discounted cash flow and net present value under the scenarios of traditional PV roof, PV water pumping pilot, PV water pumping scale-up, and PV water pumping social network, where further added value via social network was included in the business model. The results showed that the integrated PV water pumping system with social network products significantly improves the performance in areas such as the discounted payback period, internal rate of return, and return on investment.

Boutelhig et al. [74] studied the implementation of a stand-alone PV water pumping system for two farms, with static head $28 \mathrm{~m}$ and $25 \mathrm{~m}$ respectively, and with reservoir storage capacity of $50 \mathrm{~m}^{3}$ each. Also, the daily required powers was approximately $4.5 \mathrm{~kW}$ and $3 \mathrm{~kW}$, respectively was needed to extract such quantity of water. The authors concluded that the two solar pumps are very profitable for such photovoltaic water pumping system installation in that desert region for both domestic water supply and irrigation. Also, to reach an optimum PV pumping system installation, is important require a livestock tank and an optimum PV array installation.

Fiaschi et al. [75] studied the improving the effectiveness of solar pumping systems by using modular centrifugal pumps with variable rotational speed. They investigated the possibility of improving the performance of deep well solar pumping systems by using centrifugal pumps with variable rotational speed and modular number of working stages and compared with traditional systems equipped with pumps having a fixed number of stages.

Matamoros et al. [76] sized an irrigation PV system using meteorological data, having as the case study the Ecuadorian province of Guayas. Based on simulations using PVsyst software, the results showed that the simulated electro hydraulic system performs better in regions with high water deficit (low monthly 
precipitation and high evapotranspiration) compared to regions with lower water deficit.

Mohammedi et al. [77] performed an experimental study of the effect of shading PV array on a pumping system performance, where the experimental bench was installed at the Industrial Technology and Information Laboratory (LTII) in Bejaia (Algeria). With the aim of testing the performances of the proposed system, the authors suggested different array configurations which show different behaviors against partial shading conditions. Among the various conclusions, the findings showed that it is better to have a completely shaded string than several partially shaded ones.

Yahyaouia et al. [78] in "Energy and water management for drip-irrigation of tomatoes in a semi-arid district", presented and tested an autonomous off-grid system for irrigation in semi-arid areas. The algorithm was tested for a specific installation for tomatoes' irrigation during the vegetative cycle months of tomatoes in Tunisia (from March to July), including extreme situations that cause insufficient water volume in the reservoir or a depleted battery bank. The results showed that the algorithm ensures pumping the water volume needed by tomatoes, the system autonomy and the increases the batteries lifetime. Also, the proposed algorithm is general, in the sense that it can be used for PV irrigation systems of different sizes, by providing the monthly water demand and the energetic requirements.

Hamza and Taha [79] studied the performance of submersible photovoltaic solar pumping systems under conditions of Sudan. In this study, three SP4-8 Grundfos submersible pumps, was installed at three different locations in the country, where the evaluation was carried out and for each of these pumps, solar radiation in the plane of the PV array, ambient temperature, PV array voltage and current, water discharge and water delivery pressure were monitored using a data logger.

Studying the performance evaluation of solar water pumping system, was observed that power output from the solar array increases as solar intensity increases [80]. Also, the performance of PV water pump mainly depends on the water flow rate which is influenced by weather conditions at the location, especially solar irradiance and air temperature variations [81]. And, the most effective PV system contains CdTe PV module running a permanent magnet DC motor that drives a pump and only function during ample sun hours and stores water in a storage tank instead of utilizing a battery [11].

\section{Review on Wind Irrigation}

Today, wind power accounts for about $0.4 \%$ of world's electricity demand [82]. In the estimation of wind power, the most confusing concept is the mean power in the wind. The mean power in the wind depends on the mean of the cubes of the wind speeds over that time and this is different to the cube of the mean wind speed, which is why two identical wind machines (depending on the wind speed 
distribution or the frequency of occurrence of different wind speeds) located at different sites will not necessarily produce the same power output at the same mean wind speed [8]. So, summary of different authors is reviewed in this section.

\subsection{Wind Pumping System}

The variability of wind pumps depends on the wind speed. So, the mechanical wind pumps (windmills) are designed to start pumping at low wind speeds of 2.5 - $3.5 \mathrm{~m} / \mathrm{s}$. Most windmills achieve their highest overall efficiency at wind speeds of $6-9 \mathrm{~m} / \mathrm{s}$, nevertheless, these pumps normally operate best at speeds as high as $10 \mathrm{~m} / \mathrm{s}$, then the windmill furls. Mechanical wind pumps, light size, normally start pumping at wind speeds of $2-3 \mathrm{~m} / \mathrm{s}$; the medium-sized pumps at $3-4 \mathrm{~m} / \mathrm{s}$, and strong pumps at $4-5 \mathrm{~m} / \mathrm{s}$. Finally, the electrical wind turbines generally require high wind speeds to start pumping. Small turbines (about $1.5 \mathrm{~kW}$ rated output) require an average wind speed of $4-5 \mathrm{~m} / \mathrm{s}$ to start pumping. For medium and strong turbines, the wind speeds need to be much higher to start the rotor. For wind turbines with less than $1 \mathrm{~kW}$ rated output, the rotor can start at lower wind speeds $(3-5 \mathrm{~m} / \mathrm{s})$ [8].

Feitosa et al. [83] simulated the generation of electric energy from the wind source as an energetic alternative for the irrigated perimeter of Baixo-Acaraú, Brazil. In order to achieve this objective, the EOLUSOFT-Beta 1.0 NUTEMA-PUCRS software developed at PUC in Rio Grande do Sul, by the Technological Nucleus of Energy and Environment was used, and in the case of water pumping it was considered a water pump of $5 \mathrm{hp}$ with capacity to pump 10,800 $1 / h$. The results showed that with the wind speed conditions available at the study site, it is possible to provide water supply for irrigation. It should be emphasized that the average annual velocities for the study region ranged from 6 to $8.5 \mathrm{~m} / \mathrm{s}$.

In India, Kumbhar et al. [84] reviewed the experimental installation of drip irrigation using wind energy. In addition, Gosavi [85] proposed an automated system for the drip irrigation system from wind energy. The experimental results indicated that the use of wind energy was efficient to provide adequate voltage to the microcontroller as well as to the water lifting.

Gilley et al. [86] determined the potential energy savings from three types of wind powered irrigation pumping plants in selected areas in USA. The wind systems analyzed were: wind assist combustion engines; wind assist electric motors, with and without the sale of surplus electricity; and a stand-alone turbine with a reservoir for water storage. The findings indicate that the potential energy savings from wind assist units depend upon the length of the irrigation season and the wind power available during this time period. And, depending upon the region, the wind assist unit could provide as much as $30 \%$ of the seasonal irrigation pumping energy requirement. Also, in all regions studied, the amount of energy which could be sold was greater than the pumping energy saved. The stand alone system would pump water into a reservoir for use when irrigation is 
required.

Parikh [2] used average monthly wind speed data in the state of Gujurat, India, to discuss the possibility of using windmills to raise water for irrigation of mustard and wheat. Wind data were used to estimate the daily volumes of water pumped by a wind turbine under different headings. The estimated discharges during the day, at night and over a period of 24 hours, were used to calculate recurrence intervals for different water availabilities. The study shows that for the wind speed pattern considered in the study, it was found that a potential of 1214 ha of wheat and mustard can be irrigated during the winter (November-March) if only the volume pumped during the day is used for irrigation. If nocturnal discharge is also used, the minimum area of cultivation may be 1.94 ha.

Al-Jibouri [87] studied the feasibility of using wind energy for irrigation in Iraq. The research included a theoretical assessment to find solution to the technical and economic problems of water pumping in wells and explains the field of use of that energy. The study concluded from several points that it is possible to use wind energy to grow some crops in Iraq, that it is possible to increase water production by using the largest wind turbine and increasing the number of wind turbines to be installed on site.

In an attempt to utilize power of the wind for pumping the water for remotely located in habitants not connected with national power grid in Saudi Arabia, small turbines of $1-10 \mathrm{~kW}$ had been chosen in conjunction with Goulds $45 \mathrm{~J}$ model water pumps to produce energy from wind and pump water using the produced energy at 3 localities. The results showed that hat annual total water pumping capacity of $30,000 \mathrm{~m}^{3}$ is possible from a depth of total dynamic head of $50 \mathrm{~m}$ when using $2.5 \mathrm{~kW}$ proven wind turbine with hub heights $15-40 \mathrm{~m}$ at all three sites [88].

Girma et al. [89] studied the feasibility of a wind powered water pumping system for rural Ethiopia. Among results, they concluded that the life cycle cost analysis of pumping water shows that the wind powered water pumping system is more economical and feasible as compared to the Diesel-based system. Bouzidi [52] studied the viability of wind for water pumping systems in the Algerian Sahara Regions. The results showed that the wind pumping system in the Adrar region, despite the high solar energy potential, may be required under current conditions, and may even experience a large-scale use, as the availability and particularly governmental aid exist.

\subsection{Wind Pumping Performance}

In India, was developed a methodology to determine the investment per unit amount of water supplied and the levels of daily irrigation demand satisfied by the most economic windmill irrigation system at various levels of risk. The results showed that the cost per $\mathrm{m}^{3}$ of irrigation water supplied by the most economic wind mill irrigation system was found to vary between 38 paise and 71 
paise at Delhi, India, during the month of October 1983 [90].

Bragg and Schmidt [91] developed a methodology to analyze windmill water pump systems, given the characteristics of the pump and windmill separately. According to the authors, this procedure allows a number of different design problems to be treated. If the windmill is given, the appropriate pump may be chosen for a given head; or conversely the best windmill for a given pump maybe selected in an optimum fashion.

An autonomous wind energy conversion system using a BDFIG for water pumping was presented. According to the research, the proposed configuration with direct generator-load electric coupling and auxiliary stator control reduces the converter sizing and the whole system cost, while improving its performance [92].

Using meteorological conditions to study the potential of the development of water pumping using wind energy in Jordan, eleven wind sites were considered. The results showed that, in terms of the annual amount of pumped water, one is considered "favorable", which includes RasMuneef, Mafraq, and Aqaba. Others are considered to be "promising", which include H-5, Irbid, and Ma'an. The rest of sites considered are found to be "poor", which include H-4, Amman, Queen Alia's Airport, Shoubak, and Deiralla, with much smaller amounts of water output [93].

Lara et al. [94] evaluated the efficiency of a wind pumping system composed of a $3 \mathrm{~kW}$ wind generator feeding a battery bank of $48 \mathrm{~V} / 880$ Ah by means of an uncontrolled 6-pulse rectifier. That battery bank was connected a $1.5 \mathrm{~kW}$ inverter which generated $220 \mathrm{~V}$ at $50 \mathrm{~Hz}$, which supplied a single-phase electric pump of $1.1 \mathrm{~kW}$. The energy losses in each electrical component were determined using a data collection system configured to measure electrical variables in real time. The electric power generated by the wind generator for different wind speeds was on average $38 \%$ lower than the power curve provided by the manufacturer. Electromechanical tests performed in the laboratory showed the efficiency of the operation of the wind turbine generator with an average of $80 \%$. This information, together with output power, and the wind speed measured during the field operation allowed the investigators to determine the $\mathrm{Cp}$ rotor power factor, which had a maximum value of 35\%. For the stored energy components measured the data indicated that the rectifier, battery bank and inverter operated with average efficiency of $95 \%, 78 \%$ and $86 \%$, respectively. The efficiencies of the combined components showed that a maximum of $17 \%$ of wind energy would be available for pumping water.

Harries [95] presented a historical review of the experiences of design, field testing and manufacturing of (Bobs Harries Engineering Ltd.) BHEL in the development of wind pumps for pumping water in remote rural areas. Using case studies of wind turbine installation projects, the article describes the challenges faced by the spread of wind turbines in Africa and the benefits of wind turbines to rural and remote areas.

Velasco et al. [96] presented a formal theory of the water pumping system us- 
ing the wind-electric system. In this study, a structure was developed for the determination of the steady-state operating point, as well as the study of its behavior, particularly at start-up. It is shown that sufficient accumulation of kinetic energy in the wind turbine before connecting it to its load is critical to a successful start-up, even when the system is designed to operate in optimal steady-state conditions. In addition, a detailed discussion of the start-up process was presented in terms of the kinetic energy stored in the braking, the energy supplied by the pump and the electrical system losses.

\section{Overview of Biomass (Producer Gas Based Dual Fuel Engine Pumps and Producer Gas Based Dual Fuel Engine Pumps]}

Biogas technology is being seriously promoted as an important option to meet the growing energy demand of rural areas in developing countries and one of the promising applications of biogas is for mechanical power generation through internal combustion engines to drive pumps, generators, grinding mills and other equipments in rural areas [97]. Nevertheless, a limited number of studies have been reported on the use of biomass for water pumping applications due to the poor calorific value of biomass fuel [98].

A biomass gasifier water pumping system consists of a biomass gasifier (with a cooling and cleaning system) and a dual fuel powered diesel engine coupled with a centrifugal pump, and gasification is a process of converting solid/liquid fuel into gaseous fuel, known as producer gas, without leaving any solid carbonaceous residue [98]. The gasification process which results in a high proportion of gaseous products $\left(\mathrm{CO}_{2}\right.$, water, carbon monoxide, hydrogen and gaseous hydrocarbons), small quantities of char (solid product), ash, and condensable compounds (tars and oils), i.e., the producer gas is a mixture of $18 \%-22 \%$ carbon on oxide, $15 \%-19 \%$ hydrogen, $1 \%-5 \%$ methane and $45 \%-55 \%$ nitrogen with a calorific value of approximately $1100 \mathrm{kcal} / \mathrm{kg}$ [98], and can be standardized in its quality and is easier and more versatile to use than the original biomass [99].

Puig-Arnavat et al. [99] analyzed the biomass gasification models. The authors presented and analyzed several gasification models based on thermodynamic equilibrium, kinetics and artificial neural networks.

Purohit and Kandpal, in their study on techno-economics of biogas-based water pumping in India, concluded that that the measures of economic performance of community biogas based water pumping systems are higher as compared to the financial measures thus justifying state support in the initial phase of their dissemination, also, concerted efforts should be made for the large scale dissemination of community biogas based water pumping systems [97].

Mainalia et al. [100] analyzed the potential of a poly-generation system using locally available biomass resources (cow dung and agriculture residue) for providing cooking energy, electricity, and drinking water to a rural community. The authors conducted a questionnaire survey in Pani Para village with 52 households to investigate demand patterns and estimate the resource potential and 
amount of biogas needed in the poly-generation system. According to authors, further research about integrated technology must be carried out.

\section{Analysis and Comparison of Different Hybrid Pumping Systems}

These systems may be a combination of renewable sources and conventional systems, and possible hybrid systems for water pumping applications are wind and storage batteries with a backup diesel generator, wind and PV with batteries, PV and batteries, or wind turbines with batteries. The power sources (wind and solar) are mutually independent hybrids, offering greater reliability for a water pumping system than either wind or PV technology alone. Some advantages of hybrid systems are: these need not be designed for worst-case scenarios because power does not come from a single source, allow the use of smaller component sizes, which lowers the cost of the system, etc. [8].

Mehta et al. [101] proposed combining an eolic system with adequate irrigation equipment to irrigate and provide electricity for common applications in regions that do not have the public electricity grid. The use of drip irrigation provides a precise amount of water directly to the plant's root zone, providing adequate irrigation and sufficient amount of water.

In India, Kumar and Kandpal [102] evaluated Renewable energy technologies for irrigation water pumping. The approach took into account factors such as: solar radiation intensity, wind speed, availability of bovine dung and agriresidues, and their alternative uses, ground water requirements for irrigation and its availability, affordability, and propensity of the users to invest in renewable energy devices, etc. The results showed that, among the renewable energy technologies considered in the study (photovoltaic pump, windmill pump, biogas and producer gas-driven dual fuel engine pumps), the estimated utilization potential of solar PV pumps is highest followed by windmill pumps. The potential was estimated considering the prevailing conditions such as cost and technical specification of renewable energy based devices, income of farmers, among others.

Gopal et al. [98] reviewed renewable energy source water pumping systems. They concluded that renewable energy sources play a vital role in reducing the consumption of conventional energy sources and its environmental impacts in water pumping applications. The authors referred that PV and wind hybrids (with or without backup generators) are more promising to provide uninterrupted power because they work independently of each other. Also, such systems do not require that each component be oversized; but, hybrid systems are often more complex and require more skilled technicians [8].

Khattab et al. [7] studied the feasibility of hybrid renewable energy water pumping system for a Small Farm in an isolated area in El-Tour City, Sinai, Egypt, where 2 softwares (PVSYST and HOMER) were used to simulate the system performance and to reach the optimum configurations based on the objective criteria. The criteria used in economic optimization were the net present 
cost and the cost of energy, with the percent of the capacity shortage. The compared water pumping systems was PV only, PV with horizontal axis wind turbine, $\mathrm{PV}$ with vertical axis wind turbine, $\mathrm{PV}$ with horizontal axis wind turbine and diesel generator and diesel generator only. Their results showed that the net present cost and cost of energy is lower in case of PV only and increased by using wind turbine with PV system due to the lower wind speed rates in the specified location; the capacity shortage percent decreased with using diesel generator in the system, although the net present cost increased; the capacity shortage was 8.3\% for PV only, 3.9\% for PV with horizontal axis wind turbine, 3.1\% for PV with vertical axis wind turbine, $0.4 \%$ for PV with horizontal axis wind turbine/ Diesel and zero for diesel system only; monthly average wind speeds on the location were much lower than the turbine rated wind speed which leaded to nonoptimal operation of the PV/wind turbine.

Aksoy et al. [103] conducted an experimental investigation of a water pumping system driven by wind and solar energy for irrigation purpose. The authors observed that the daily mean of produced electricity by the system in July was enough to pump daily average $44.1 \mathrm{~m}^{3} /$ day of water from the depth of $2.5 \mathrm{~m}$ and totally $1368 \mathrm{~m}^{3}$ of water during the month. It was also found that the amount of pumped water was sufficient to meet water need of the agricultural products that were 12.4 decares (da) of sugar beet, 13.0 da of potatoes, $13.4 \mathrm{da}$ of corn, $13.6 \mathrm{da}$ green bean and $10.8 \mathrm{da}$ of sun flower with the drip irrigation method. In relation to the hybrid system (PV/wind) was also developed a methodology for the optimal design of pumping system with water storage to supply drinking water to households in remote areas [104].

Vick and Neal [105] intended to determine advantages or disadvantages of using a hybrid system over using a wind turbine or a solar PV array alone; if the wind turbine or solar PV array interfered with the output of the other; and which hybrid system was the most efficient for the location. For such, they analyzed individually off-grid wind turbine and solar photovoltaic array water pumping systems and combined as a hybrid system. In this study, the wind turbine used was rated at $900 \mathrm{~W} \mathrm{AC}$, also, 3 different solar PV arrays were analyzed, and they were rated at 320,480, and $640 \mathrm{~W}$ DC. Among several results, they concluded that hybrid system appeared to be the most efficient of the systems tested for the Southern Great Plains, because this pumped 28\% more water during the greatest water demand month than the wind turbine and PV systems would have pumped individually. Making a comparison between wind turbine and solar PV powered helical pumps for livestock watering, it was possible to see that solar powered helical pump systems is the best option to the livestock water requirement in the Southern Great Plains [106].

Habib et al. [107] presented a procedure for optimizing the size of a hybrid photovoltaic/wind energy system. This procedure was applied for the sizing of solar/wind hybrid system that is considered to produce a constant load of $5 \mathrm{~kW}$ in the Dhahran area, Saudi Arabia. For this study, the results indicated that the optimal solar/wind ratio that resulted in the minimum capital cost was $70 \%$. 
Laamari et al. [108] presented an optimization method for a hybrid (wind-solar) autonomous system designed for pumping water. The results confirm that it is technically advantageous to use renewable energy for pumping water.

Abuashour et al. [109] presented a stand-alone Wind/PV hybrid power system supplying a three-phase induction motor for pumping applications. In this study, the authors concluded that the proposed hybrid stand-alone power system can withstand step changes in the load coupled to the motor and step changes in the solar irradiance levels which indicates the robustness and proves the reliability of the integration between different system components.

Study state that the use of PV cells in an all electric system or in a hybrid system appears to be an almost ideal solar energy application for pumping irrigation water, however, is important that the power conditioning can be eliminated, and also the cost of these systems can be decreased [110].

Moonsri et al. [111] in "Hybrid Energy Thermal Water Pump for Producing Hot Water from a Shallow Well in Thailand", observed that for suction heads of 1 and $3 \mathrm{~m}$, the total pump efficiency was around $0.012 \%-0.027 \%$ and the thermal efficiency was around $32.5 \%-36.3 \%$. The authors concluded that this system (hybrid energy thermal water pump) is more essential for agriculture in the rural area.

In Libya, Sirte city, Alkarrami et al. [109] using HOMER Pro, HOMER Beta, and iHOGA softwares, compared the size optimization of standalone PV/Wind turbine hybrids system for water pumping. The results showed that the optimal system suggested by iHOGA had the lowest net present cost (NPC) but the highest cost of energy (COE), whereas HOMER Pro had the highest net present cost but the lowest cost of energy.

Handayani and Hulukati [112] developed a hybrid solar power water tank pumping system prototype, which can utilize electricity provided both by electricity grid and solar PV.

Kumar and Singh [113] proposed and analyzed the performance of a brushless DC motor driven water pumping fed by PV battery hybrid source. According to the authors, this grid independent system has been found more useful for remote and isolated regions.

In Egypt, Shouman et al. [114] performed an economic analysis of the water pumping system for irrigation using solar and diesel. The study considered 3 systems for water pumping, namely PV only, hybrid PV-diesel and diesel only and used the HOMER software and theoretical equations governing the PV operation to get the optimal system design and the related economic analysis. The results showed that PV energy is more advantageous than diesel, in terms of the net present cost and the cost of energy. Also, they concluded that diesel pumps are typically characterized by a lower capital cost but a very high operation and maintenance cost. Solar is the opposite, with a considerably higher capital cost but very low ongoing operation and maintenance costs.

Hammad [115] analyzed the economics of water pumping by diesel generation system, the PV generation system, the mechanical wind pumping system 
and electrical wind pumping system. Their results showed lower costs for both $\mathrm{PV}$ and mechanical wind pumping system than diesel generation, and higher costs for the electrical wind pumping system. Also, the results showed that at low capacities it is more economical to use PV generation than other methods.

In India, Purohit [116] developed a simple framework for financial evaluation of renewable energy technologies such as PV pump, windmill pump, biogas and producer gas-driven dual fuel engine pumps for irrigation water pumping. $\mathrm{He}$ concluded that, except the biogas-based dual fuel engine pumps and appropriate designs of windmill pumps in selected niche areas, the renewable energy technologies for irrigation water pumping are presently not financially attractive to the users of diesel/electric pumps. According to the author, the use of producer gas-driven dual fuel engine pumps makes financial sense at locations where the biomass feedstock is freely available. Also, the use of producer gas-driven dual fuel engine pumps at higher capacity utilization factor of the system (that is, it is the fraction of time that the system operates in a year) will also make these systems financially more attractive as compared to the PV and windmill pumps.

Powell et al. [117] researched the investment analysis of solar energy in a hybrid diesel irrigation pumping system. According to the authors, an investment analysis using a discounted cash flow over 25 years showed a $23 \%$ internal rate of return and payback over 5 years. Also, refereed that the benefits of installing a renewable fuel source included lower greenhouse gas emissions produced and less labor to monitor and service traditional diesel irrigation plant.

\section{General Review on Renewable Sources Irrigation of Mozambique}

Semiarid areas characterized by marginal rainfall amounts restricting rainfed crop yields, highly seasonal rainfall with long dry seasons, unpredictable rainfall in the growth season, and scarcity of potable water for humans and livestock, are already experiencing the impacts of warming and shifting rainfall patterns [118].

\subsection{Choosing the Kind of Energy Source}

Among several factors, the choice of the energy source to be used for the water pumping system in a given location will depend on technico and economical aspects of the power source, location, social and institutional factors and the availability of water at the location where the system is to be installed. The water may be superficial or underground, depending on availability, demand, topography, hydrological formation of the ground, annual rainfall, characteristics of the ground aquifer and the type of proposed use [8].

\subsection{Water Demand}

Table 1 shows the estimation maximum daily water demand for various types of crop irrigation. To estimate the water demand for the irrigation of a given crop is complex, but normally, water demand for irrigation varies from crop to crop and changes with the type of soil, soil preparation and irrigation methods, rainfall 
Table 1. Estimated maximum daily water demand for various types of crop irrigation [8].

\begin{tabular}{cc}
\hline Crops & Daily water requirement $\left(\mathrm{m}^{3} / \mathrm{ha}\right)$ \\
\hline rice & 100 \\
Rural villages farms & 60 \\
cereals & 45 \\
Sugar cane & 65 \\
cotton & 55 \\
\hline
\end{tabular}

regimes, and other meteorological factors like temperature, humidity, wind speed, and cloud cover. Nevertheless, all irrigation systems need to be designed for peak water demands, it's because some crops require a maximum water supply for a relatively short growing season. Irrigation water pumps are characterized by the need for large quantities of water, thus, wind- and PV-powered irrigation pumps are usually recommended for surface water resources or for shallow wells for high yield [8].

\subsection{Description of Study Area}

Mozambique is one of the poorest countries in the world and is located on the east coast of southern Africa on the Indian Ocean. The country is bordered by the United Republic of Tanzania in the north, South Africa in the south, Swaziland in the southwest and South Africa, Zimbabwe, Zambia in the west, and Malawi in the northwest. The country has a total area of 799,380 $\mathrm{km}^{2}$.

Irrigation potential was estimated to be around 3.1 million ha, while other sources give 3.3 million ha [118]. Close to $40 \%$ (36 million ha) of the 800,000 $\mathrm{km}^{2}$ of Mozambique territory are arable land. At present only $10 \%$ of the total arable land is under cultivation of which only $1 \%$ is in the hands of commercial agriculture. The remaining $99 \%$ of the cultivated land is in the hands of subsistence farmers and are distributed by close to 4.0 million small farms of slightly above 1 ha and less than 10 ha in size [119]. However, the major areas suitable for irrigation are in the centre and north. The southern provinces have the highest need for irrigation but have only a small share of the land suitable for irrigation [118].

In terms of climate, Mozambique has tropical to subtropical, in the northern and central parts, to dry semi-arid steppe and dry arid desert in the south, being highly exposed to harmful climatic events, including droughts, floods and cyclones. The distribution of precipitation in the whole country is uneven, with the northern rainiest region and the driest southern region, where some localities receive only $300 \mathrm{~mm}$ of rainfall per year. During the dry season, when the greatest amount of precipitation occurs, the northern region receives 150 - $300 \mathrm{~mm}$ of rain, while the south receives $50-150 \mathrm{~mm}$ per month. The interior regions of southern Mozambique, as parts of Gaza province, have a long dry season, with precipitation ranging from 500 to $600 \mathrm{~mm}$ per year, and as a consequence, among several disasters, they suffer from lack of access to water, limiting this way agricultural production [119] [120] [121]. Figure 3 shows the map of the 


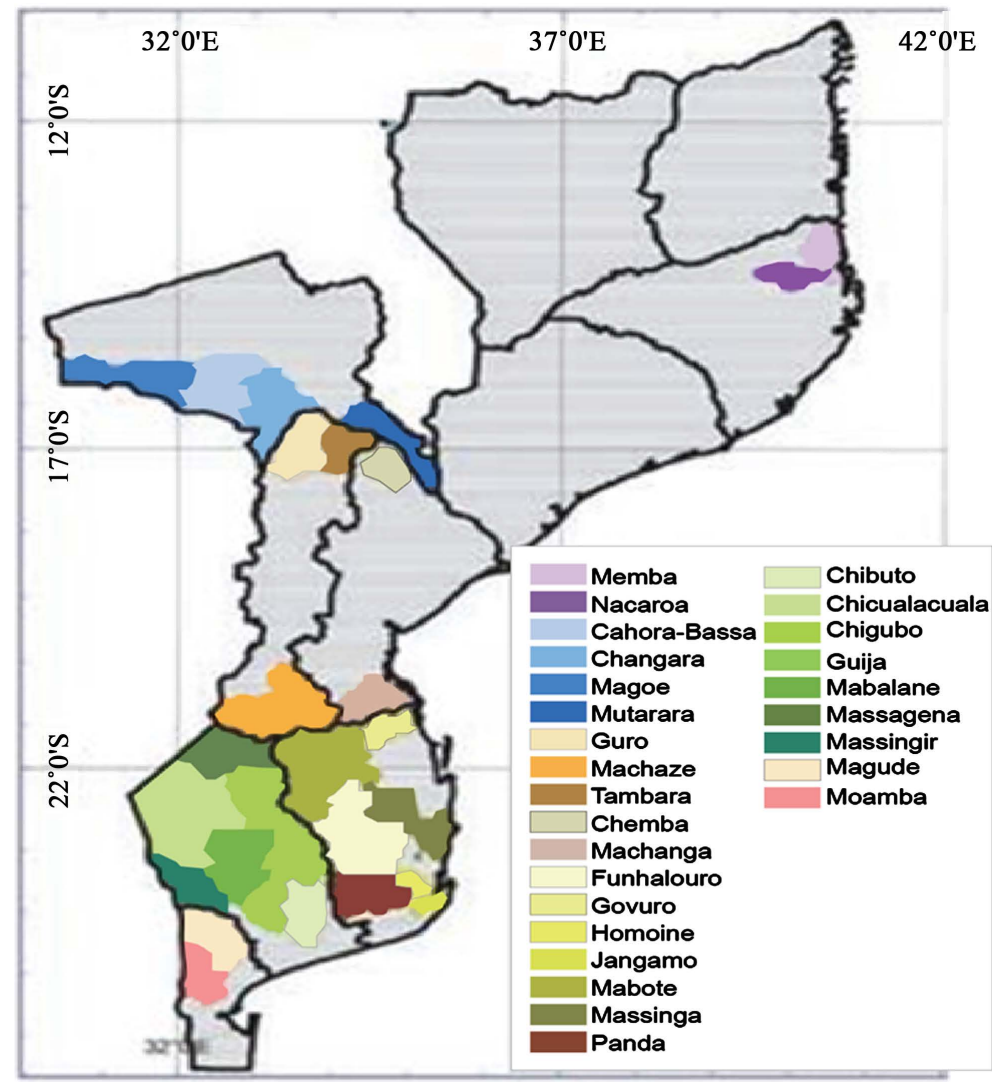

Figure 3. Location of arid and semi-arid zones of Mozambique.

arid and semi arid zones of Mozambique.

\subsection{Renewable Resources}

Mozambique has a great potential for renewable energy, including solar and wind. Share of renewable energy in the primary energy supply is still very low and almost insignificant despite the effort done to overcame this situation [122]. For example, the use of solar power, In addition to saving costs on fuel, minimizes time spent in sourcing conventional biomass and diesel, enabling more time for other productive activities [120].

\subsubsection{Solar Resource}

Mozambique has a good solar resource, consistent throughout the territory and stable throughout the year. On a global scale, solar irradiation essentially depends on geometry and movement of the planet in relation to the sun, however on a local scale the changes in solar irradiation are mainly due to the topography, that is, variation in elevation, slope, aspect and shading. Mozambique has high global irradiation on the horizontal plane when compared with other good locations in Europe and Asia, being quite close to some of the best locations in the world, like South Africa and California [121].

In Mozambique the global horizontal irradiation varies between 1785 and $2206 \mathrm{kWh} / \mathrm{m}^{2} /$ year. Based on the global irradiation on inclined surface, in the 
analysis of the terrain slope, forest density and flooded areas, the solar potential of Mozambique is 23 TWp. Solar is the primary renewable resource of Mozambique [121].

Cuamba et al. [123] in their study presented a general characterisation of the global, diffuse and direct solar radiation fields in Mozambique. The results showed that the average of solar radiation in the country is of $5.7 \mathrm{kWh} / \mathrm{m}^{2} /$ day. Also, the data revealed that there is an evident increase of the value of the global solar radiation from south to north along the coast line. This was expected, as the radiation should increase as one move to the equatorial line. Nevertheless, in the interior there is a decrease of the value of global solar radiation from south to north.

Maps of monthly mean daily direct normal insolation for June and December and maps of the annual mean direct normal and global insolation show that the behavior of the iso-insolation curves is affected, to a high degree, by the prevailing trade winds and mountain chains of Mozambique [124].

\subsubsection{Wind Resource}

Wind power in Mozambique is still at early stages of development [125]. Nevertheless, Mozambique is characterized by winds of moderate-low intensity with average speeds between 4 and 6 meters per second at 80 meters above ground level, except in the south of the country and in the highlands of the Center and North where winds can reach higher speeds. The highest wind energy potential can be observed in the provinces of Maputo, Tete, and on the coast of Sofala, Inhambane and Gaza [121].

\subsubsection{Biomass}

Mozambique currently has more than 1.7 million hectares of forest plantation concessions awarded and has above average annual increment conditions for dedicated plantations. The forest biomass, used as an energy source to produce electricity or heat, can be derived from conventional logging woody surplus or residues (branches and canopies from forest cuts or from trees removed in thinning) or from entire trees from dedicated forest plantations. Its use as an energy source usually occurs in electricity power plants by burning it in boilers to produce steam that once expanded, generates electricity. These plants should be located in the vicinity of areas with forest concessions and/or forest plantations [121].

Other types of biomass found in Mozambique can be used as a complementary energy source to forest biomass. From these stand out the residues from agroindustries (rice husk, coconut shell and other materials), waste from wood manufacturing industries (sawdust from sawmills, furniture factories and carpentry) as well as the use of plant materials in the removal and conversion of declining palm affected by diseases [121].

\section{Results and Discussion}

The major objective of this research is to review on renewable energy systems to 
irrigation in arid and semi-arid. In this section, some important results from various researchers will be presented and discussed.

- Solar thermal pumping system for irrigation is still not very common, there are still some limitations to the use of this technology. However, studies have been done with the aim of reversing the present scenario.

- Thermal solar water pumps are low cost and low maintenance pumps with a pumping capacity of $0.2-1 \mathrm{~m}^{3} /$ hour in a dynamic head of 1.5 to $5 \mathrm{~m}$ and the average daily efficiency of the system varies between $10 \%$ and $13 \%$. However, there is an ideal vapour mass flow, where the ideal efficiency can reach about $18 \%$.

- The suitability of solar energy for raising water for plant irrigation is undeniable due to the complementarity between solar radiation and the water needs of plants. The more intensely the sun is shining, the greater the power to provide irrigation water and vice versa. Periods of maximum demand for water coincide with periods of maximum solar radiation.

- PV systems for irrigation have the advantage of practically no maintenance when compared to manual pumps or internal combustion. It's easy to install and does not pollute the environment. In economic terms, solar water pumping is economically viable compared to electricity or diesel-based systems for irrigation and water supply in rural, urban, and remote regions. PV energy is more advantageous than diesel in terms of the net present cost and the cost of energy, that is, diesel pumps are typically characterized by a lower cost of capital, but a very high operating and maintenance cost. The solar is the opposite, with a considerably higher cost of capital, but very low operating and maintenance costs. Unfortunately, since the initial investment value of solar energy is still relatively high, it does not allow small farmers, especially in the arid and semi-arid zones, to have easy access to these systems.

- PV energy is more competitive when the irrigation system with which it operates has a low total dynamic. So, PV energy is more cost-competitive when used to power a micro irrigation system compared to an aerial sprinkler system. In addition, PV energy for irrigation is competitive in cost with traditional energy sources for small remote applications if the total system design and the time of use are carefully considered and arranged to use solar energy as efficiently as possible. In sum, water fed by PV pumping systems are attractive for small-scale irrigation in areas where water is scarce and access to AC energy is limited.

- The performance of PV water pump mainly depends on the water flow rate which is influenced by weather conditions at the location, especially solar irradiance and air temperature variations, also the performance of the operation of directly PV powered direct current permanent magnet motor mainly depends on the incident solar radiation, operating cell temperature, DC motor and propeller load parameters.

- The performance of directly coupled water pumping photovoltaic system about $1.5 \mathrm{kWp}$, DC engine and centrifugal pump, does not reach $30 \%$. But 
despite this, the system is clearly suitable for low head irrigation in remote areas not connected to the national grid and where access to water emerges as a priority issue than access to technology. The system works without battery and complex electronic control, therefore, not only the initial cost is low, but also the maintenance, repair and replacement cost can be saved. Also, directly coupled system reaches steady state soon after any abrupt change.

- Determinating the potential energy savings from three types of wind powered irrigation pumping plants in some selected areas, the findings indicated that the potential energy savings from wind assist units depends upon the length of the irrigation season and the wind power available during this time period. Besides, depending upon the region, the wind assist unit could provide as much as $30 \%$ of the seasonal irrigation pumping energy requirement. The stand alone system would pump water into a reservoir for use when irrigation is required.

- In terms economics, the life cycle cost analysis of pumping water shows that the wind powered water pumping system is more economical and feasible as compared to the Diesel-based system.

- The measures of economic performance of community biogas based water pumping systems are higher as compared to the financial measures thus justifying state support in the initial phase of their dissemination, also, concerted efforts should be made for the large scale dissemination of community biogas based water pumping systems.

- PV and wind hybrids (with or without backup generators) are more promising to provide uninterrupted power because they work independently of each other. Such systems do not require that each component be oversized. However, hybrid systems are often more complex and require more skilled technicians.

- The use of producer gas-driven dual fuel engine pumps makes financial sense at locations, where the biomass feedstock is freely available. Also, the use of producer gas driven dual fuel engine pumps at higher CUF will also make these systems financially more attractive as compared to the PV and windmill pumps.

\section{Conclusion}

Water and energy are strongly interconnected because water is needed to produce, transport, and use all forms of energy to some degree; and energy is required for the extraction, treatment and distribution of water, as well as its collection and treatment after use [126]. So, a detailed review about renewable energy systems for irrigation is presented. The study focused on solar thermal pumping system as well as performance, photovoltaic solar pumping system as well as performance, wind pumping system and using biomass. Through the literary review, it is possible to see the importance of renewable energy for small-scale irrigation, especially in the arid and semi-arid zones, that is, results 
confirm that it is technically advantageous to use renewable energy for pumping water. The solar photovoltaic system in small-scale irrigation has been more used, followed by the wind system. Solar thermal systems pumping as well as biomass pumping are still in slow steps. Mozambique has the potential to use both the solar and wind pumping systems, so that the country should increasingly focus on these systems with more emphasis on irrigation, especially in arid and semi-arid regions, in order to boost agricultural production. The authors recommend identifying the appropriate hybrid system that can be used for irrigation in the arid and semi-arid zones. However, the authors are already carrying out these researches.

\section{Acknowledgements}

Acknowledgment addressed to the Ministry of Science and Technology, Higher Education and Professional Technician of Mozambique for the financing the Ph.D. research program.

\section{Conflicts of Interest}

The authors declare no conflicts of interest regarding the publication of this paper.

\section{References}

[1] Bekhet, H.A. and Abdullah, A. (2010) Energy Use in Agriculture Sector: Input-Output Analysis. International Business Research, 3, 111-121.

https://doi.org/10.5539/ibr.v3n3p111

[2] Bhattacharya, A.K. and Parikh, M.M. (1984) Wind Data Analysis for Studying the Feasibility of Using Windmills for Irrigation. Energy for Agriculture, 3, 129-136. https://doi.org/10.1016/0167-5826(84)90015-9

[3] International Renewable Energy Agency (2016) Solar Pumping for Irrigation: Improving Livelihoods and Sustainability.

[4] Isaias, D.H.S., Cuamba, B.C., Leao, A.J. and Banze, B. (2019) Estimation of the Potential of Rainwater Harvesting for Domestic Use in Arid and Semi-Arid Regions from Mozambique: Study of Moamba. International Journal of Scientific \& Engineering Research, 10, 1119-1129.

[5] Gallon, J.F., Gallon, I., Baseggio, N., Gomes De Oliveira, F., Luisa, M. and Menegotto, A. (2015) Irrigação por Gotejamento Uso da Água com Tecnologia para a Produção.

[6] UN-Water (2006) Coping with Water Coping with Water Scarcity.

[7] Khattab, N.M., Badr, M.A., El Shenawy, E.T., Sharawy, H.H. and Shalaby, M.S. (2016) Feasibility of Hybrid Renewable Energy Water Pumping System for a Small Farm in Egypt. International Journal of Applied Engineering Research, 11, 7406-7414.

[8] Argaw, N., Foster, R. and Ellis, A. (2003) Renewable Energy for Water Pumping Applications in Rural Areas.

[9] Aliyu, M., Hassan, G., Said, S.A., Siddiqui, M.U., Alawami, A.T. and Elamin, I.M. (2018) A Review of Solar-Powered Water Pumping Systems. Renewable \& Sustainable Energy Reviews, 87, 61-76. https://doi.org/10.1016/j.rser.2018.02.010 
[10] Wazed, S.M., Hughes, B.R., Connor, D.O. and Calautit, J.K. (2018) A Review of Sustainable Solar Irrigation Systems for Sub-Saharan Africa. Renewable \& Sustainable Energy Reviews, 81, 1206-1225. https://doi.org/10.1016/j.rser.2017.08.039

[11] Wazed, S.M., Hughes, B.R., O'Connor, D. and Calautit, J.K. (2017) Solar Driven Irrigation Systems for Remote Rural Farms. Energy Procedia, 142, 184-191. https://doi.org/10.1016/j.egypro.2017.12.030

[12] Chandel, S., Naik, M., et al. (2015) Review of Solar Photovoltaic Water Pumping System Technology for Irrigation: Heriot-Watt University Library Resources. $R e-$ newable \& Sustainable Energy Reviews, 49, 1084-1099. https://doi.org/10.1016/j.rser.2015.04.083

[13] Wong, Y.W. and Sumathy, K. (1999) Solar Thermal Water Pumping Systems: A Review. Renewable \& Sustainable Energy Reviews, 3, 185-217. https://doi.org/10.1016/S1364-0321(98)00018-5

[14] Lin, X. (1999) Flash Floods in Arid and Semi-Arid Zones. Technical Documents Hydrology, No. 23, 65.

[15] Spencer, L.C. (1989) A Comprehensive Review of Small Solar-Powered Heat Engines: Part II. Research since 1950- “Conventional” Engines up to $100 \mathrm{~kW}$. Solar Energy, 43, 197-210. https://doi.org/10.1016/0038-092X(89)90020-0

[16] Nederstigt, J. and Bom, G.J. (2014) Renewable Energy for Smallholder Irrigation. SNV Technical Reviewers.

[17] Von Oppen, M. and Chandwalker, K. (2005) Solar Power for Irrigation. Refocus, 2, 24-26. https://doi.org/10.1016/S1471-0846(01)80045-7

[18] Mahkamov, K. and Orda, E.P. (2005) Solar Thermal Water Pumps: A Preliminary Analysis of the Working Process. Journal of Solar Energy Engineering, 127, 29-36. https://doi.org/10.1115/1.1767191

[19] Al-Sakaf, O.H. (1998) Application Possibilities of Solar Thermal Power Plants in Arab Countries. Renewable Energy, 14, 1-9. https://doi.org/10.1016/S0960-1481(98)00039-1

[20] Ahmadi, M.H., Ahmadi, M.A. and Pourfayaz, F. (2017) Thermal Models for Analysis of Performance of Stirling Engine: A Review. Renewable \& Sustainable Energy Reviews, 68, 168-184. https://doi.org/10.1016/j.rser.2016.09.033

[21] Sumathy, K., Venkatesh, A. and Sriramulu, V. (1996) Thermodynamic Analysis of a Solar Thermal Water Pump. Solar Energy, 57, 155-161. https://doi.org/10.1016/S0038-092X(96)00050-3

[22] Wong, Y.W. and Sumathy, K. (2001) Thermodynamic Analysis and Optimization of a Solar Thermal Water Pump. Applied Thermal Engineering, 21, 613-627. https://doi.org/10.1016/S1359-4311(00)00065-X

[23] Bataineh, K.M. (2016) Optimization Analysis of Solar Thermal Water Pump. Renewable \& Sustainable Energy Reviews, 55, 603-613. https://doi.org/10.1016/j.rser.2015.10.146

[24] Baral, S., Kim, D., Yun, E. and Kim, K.C. (2015) Experimental and Thermoeconomic Analysis of Small-Scale Solar Organic Rankine Cycle (SORC) System. Entropy, 17, 2039-2061. https://doi.org/10.3390/e17042039

[25] Bandaru, R., Muraleedharan, C. and Pavan, P.K. (2019) Modelling and Dynamic Simulation of Solar-Thermal Energy Conversion in an Unconventional Solar Thermal Water Pump. Elsevier B.V., Amsterdam. https://doi.org/10.1016/j.renene.2018.10.108

[26] Kokila, R.N. and Rajakumar, S. (2014) Thermal Performance Analysis and Optimi- 
zation of Solar Assisted Heat Pump Water Heater. Applied Mechanics and Materials, 592-594, 2416-2421.

https://doi.org/10.4028/www.scientific.net/AMM.592-594.2416

[27] Kurhe, N., Funde, A., Gokhale, P., Jadkar, S., Ghaisas, S. and Date, A. (2017) Development of Low Temperature Heat Engine for Water Pumping Application. Energy Procedia, 110, 292-297. https://doi.org/10.1016/j.egypro.2017.03.142

[28] Delgado-Torres, A.M. (2009) Solar Thermal Heat Engines for Water Pumping: An Update. Renewable \& Sustainable Energy Reviews, 13, 462-472. https://doi.org/10.1016/j.rser.2007.11.004

[29] Sitranon, J., Lertsatitthanakorn, C., Namprakai, P., Prathinthong, N., Suparos, T. and Roonprasang, N. (2014) Performance Enhancement of Solar Water Heater with a Thermal Water Pump. Journal of Energy Engineering, 141, Article ID: 04014036. https://doi.org/10.1061/(ASCE)EY.1943-7897.0000216

[30] Spindler, K., Chandwalker, K. and Hahne, E. (1996) Small Solar (Thermal) Water-Pumping System. Solar Energy, 57, 69-76. https://doi.org/10.1016/0038-092X(96)00043-6

[31] Closas, A. and Rap, E. (2017) Solar-Based Groundwater Pumping for Irrigation: Sustainability, Policies, and Limitations. Energy Policy, 104, 33-37.

https://doi.org/10.1016/j.enpol.2017.01.035

[32] Nath Maurya, V., Ogubazghi, G., Prasad Misra, B., Kumar Maurya, A. and Kaur Arora, D. (2015) Scope and Review of Photovoltaic Solar Water Pumping System as a Sustainable Solution Enhancing Water Use Efficiency in Irrigation. American Journal of Biological and Environmental Statistics, 1, 1-8.

[33] Sontake, V.C. and Kalamkar, V.R. (2016) Solar Photovoltaic Water Pumping System-A Comprehensive Review. Renewable \& Sustainable Energy Reviews, 59, 1038-1067. https://doi.org/10.1016/j.rser.2016.01.021

[34] Shinde, V. and Wandre, S. (2015) Solar Photovoltaic Water Pumping System for Irrigation: A Review. African Journal of Agricultural Research, 10, 2267-2273. https://doi.org/10.5897/AJAR2015.9879

[35] Hartung, H. and Pluschke, L. (2018) The Benefits and Risks of Solar Powered Irrigation.

[36] Eker, B. (2005) Solar Powered Water Pumping System-Google Search.

[37] Moeeni, S.A. and Alam, M. (2016) Solar Photovoltaic Water Pumping System for Pressurised Irrigation. Environmental and Earth Sciences Research Journal, 3, 41-43. https://doi.org/10.18280/eesrj.030302

[38] Burney, J., Woltering, L., Burke, M., Naylor, R. and Pasternak, D. (2010) Solar-Powered Drip Irrigation Enhances Food Security in the Sudano-Sahel. Proceedings of the National Academy of Sciences of the United States of America, 107, 1848-1853. https://doi.org/10.1073/pnas.0909678107

[39] Narale, E.P.D., Rathore, N.S. and Kothari, S. (2013) Study of Solar PV Water Pumping System for Irrigation of Horticulture Crops. International Journal of Engineering Science Invention, 2, 2319-6734.

[40] Cuadros, F., López-Rodríguez, F., Marcos, A. and Coello, J. (2004) A Procedure to Size Solar-Powered Irrigation (Photoirrigation) Schemes. Solar Energy, 76, 465-473. https://doi.org/10.1016/j.solener.2003.08.040

[41] Dursun, M. and Ozden, S. (2012) Application of Solar Powered Automatic Water Pumping in Turkey. International Journal of Computer and Electrical Engineering, 4, 161-164. https://doi.org/10.7763/IJCEE.2013.V5.471 
[42] Kyi, M.S., Maw, L. and Tun, H.M. (2016) Study of Solar PV Sizing of Water Pumping System for Irrigation of Asparagus. International Journal of Scientific \& Technology Research, 5, 71-75.

[43] Barrueto Guzmán, A., Barraza Vicencio, R., Ardila-Rey, J., Núñez Ahumada, E., González Araya, A. and Arancibia Moreno, G. (2018) A Cost-Effective Methodology for Sizing Solar PV Systems for Existing Irrigation Facilities in Chile. Energies, 11, 1853. https://doi.org/10.3390/en11071853

[44] Martins, E.G.O., Diniz, A.M.F. and Araujo, R.D. (2015) Irrigação com aproveitamento da água das chuvas e bombeamento fotovoltaico.

[45] Rawat, R., Kaushik, S.C. and Lamba, R. (2016) A Review on Modeling, Design Methodology and Size Optimization of Photovoltaic Based Water Pumping, Standalone and Grid Connected System. Renewable \& Sustainable Energy Reviews, 57, 1506-1519. https://doi.org/10.1016/j.rser.2015.12.228

[46] Zegeye, M., Ramakrishnan, V.S. and Premalatha, M. (2017) Optimal Solar Water Pumping System for Small Scale Irrigation: A Case Study on Economical Sizing for Dangila Area of Ethiopia. International Journal of Scientific Engineering and Applied Science (IJSEAS), 3, 1-5.

[47] Yu, Y., Liu, J., Wang, H. and Liu, M. (2011) Assess the Potential of Solar Irrigation Systems for Sustaining Pasture Lands in Arid Regions-A Case Study in Northwestern China. Applied Energy, 88, 3176-3182. https://doi.org/10.1016/j.apenergy.2011.02.028

[48] Campana, P.E., et al. (2017) Suitable and Optimal Locations for Implementing Photovoltaic Water Pumping Systems for Grassland Irrigation in China. Applied Energy, 185, 1879-1889. https://doi.org/10.1016/j.apenergy.2016.01.004

[49] Schmitter, P., Kibret, K.S., Lefore, N. and Barron, J. (2018) Suitability Mapping Framework for Solar Photovoltaic Pumps for Smallholder Farmers in Sub-Saharan Africa. Applied Geography, 94, 41-57. https://doi.org/10.1016/j.apgeog.2018.02.008

[50] Gao, X., et al. (2013) Feasibility Evaluation of Solar Photovoltaic Pumping Irrigation System Based on Analysis of Dynamic Variation of Groundwater Table. Applied Energy, 105, 182-193. https://doi.org/10.1016/j.apenergy.2012.11.074

[51] Sadrul Islam, A.K.M., Mondal, M.A.H. and Ahiduzzaman, M. (2010) A Case Study of Grid Connected Solar PV Irrigation System in Semi-Arid Region of Bangladesh. International Journal of Sustainable Water and Environmental Systems, 1, 33-38. https://doi.org/10.5383/swes.0101.008

[52] Bouzidi, B. (2011) Viability of Solar or Wind for Water Pumping Systems in the Algerian Sahara Regions-Case Study Adrar. Renewable \& Sustainable Energy Reviews, 15, 4436-4442. https://doi.org/10.1016/j.rser.2011.07.108

[53] Vick, B.D. and Clark, R.N. (2011) Experimental Investigation of Solar Powered Diaphragm and Helical Pumps. Solar Energy, 85, 945-954.

https://doi.org/10.1016/j.solener.2011.02.011

[54] Odeh, I., Yohanis, Y.G. and Norton, B. (2006) Influence of Pumping Head, Insolation and PV Array Size on PV Water Pumping System Performance. Solar Energy, 80, 51-64. https://doi.org/10.1016/j.solener.2005.07.009

[55] Carrillo-Cobo, M.T., Camacho-Poyato, E., Montesinos, P. and Rodriguez-Diaz, J.A. (2014) Assessing the Potential of Solar Energy in Pressurized Irrigation Networks. The Case of Bembézar MI Irrigation District (Spain). Spanish Journal of Agricultural Research, 12, 838-849. https://doi.org/10.5424/sjar/2014123-5327

[56] Atlam, O. and Kolhe, M. (2013) Performance Evaluation of Directly Photovoltaic Powered DC PM (Direct Current Permanent Magnet) Motor-Propeller Thrust 
System. Energy, 57, 692-698. https://doi.org/10.1016/j.energy.2013.05.052

[57] Kolhe, M., Joshi, J.C. and Kothari, D.P. (2004) Performance Analysis of a Directly Coupled Photovoltaic Water-Pumping System. IEEE Transactions on Energy Conversion, 19, 613-618. https://doi.org/10.1109/TEC.2004.827032

[58] Arab, A.H., Chenlo, F., Mukadam, K. and Balenzategui, J.L. (1999) Performance of PV Water Pumping Systems. Renewable Energy, 18, 191-204. https://doi.org/10.1016/S0960-1481(98)00780-0

[59] Lal, S., Kumar, P. and Rajora, R. (2013) Performance Analysis of Photovoltaic Based Submersible Water Pump. International Journal of Engineering \& Technology, 5, 552-560.

[60] Reca, J., Torrente, C., López-Luque, R. and Martínez, J. (2016) Feasibility Analysis of a Standalone Direct Pumping Photovoltaic System for Irrigation in Mediterranean Greenhouses. Renewable Energy, 85, 1143-1154. https://doi.org/10.1016/j.renene.2015.07.056

[61] Ghoneim, A.A. (2006) Design Optimization of Photovoltaic Powered Water Pumping Systems. Energy Conversion and Management, 47, 1449-1463. https://doi.org/10.1016/j.enconman.2005.08.015

[62] Elkholy, M.M. and Fathy, A. (2016) Optimization of a PV Fed Water Pumping System without Storage Based on Teaching-Learning-Based Optimization Algorithm and Artificial Neural Network. Solar Energy, 139, 199-212. https://doi.org/10.1016/j.solener.2016.09.022

[63] Mokeddem, A., Midoun, A., Kadri, D., Hiadsi, S. and Raja, I.A. (2011) Performance of a Directly-Coupled PV Water Pumping System. Energy Conversion and Management, 52, 3089-3095. https://doi.org/10.1016/j.enconman.2011.04.024

[64] Alghuwainem, S.M. (1996) Performance Analysis of a PV Powered dc Motor Driving a 3-Phase Self-Excited Induction Generator. IEEE Transactions on Energy Conversion, 11, 155-161. https://doi.org/10.1109/60.486590

[65] Tiwari, A.K. and Kalamkar, V.R. (2016) Performance Investigations of Solar Water Pumping System Using Helical Pump under the Outdoor Condition of Nagpur, India. Renewable Energy, 97, 737-745. https://doi.org/10.1016/j.renene.2016.06.021

[66] Benghanem, M., Daffallah, K.O., Joraid, A.A., Alamri, S.N. and Jaber, A. (2013) Performances of Solar Water Pumping System Using Helical Pump for a Deep Well: A Case Study for Madinah, Saudi Arabia. Energy Conversion and Management, 65, 50-56. https://doi.org/10.1016/j.enconman.2012.08.013

[67] Kou, Q., Klein, S.A. and Beckman, W.A. (1998) A Method for Estimating the Long-Term Performance of Direct-Coupled PV Pumping Systems. Solar Energy, 64, 33-40. https://doi.org/10.1016/S0038-092X(98)00049-8

[68] Hamidat, A., Benyoucef, B. and Boukadoum, M.T. (2007) New Approach to Determine the Performances of the Photovoltaic Pumping System. Rev. des Energies Renouvelables ICRESD-07, Tlemcen, 101-107.

[69] Jones, M.A., Odeh, I., Haddad, M., Mohammad, A.H. and Quinn, J.C. (2016) Economic Analysis of Photovoltaic (PV) Powered Water Pumping and Desalination without Energy Storage for Agriculture. Desalination, 387, 35-45. https://doi.org/10.1016/j.desal.2016.02.035

[70] Picazo, M.Á.P., Juárez, J.M. and García-Márquez, D. (2018) Energy Consumption Optimization in Irrigation Networks Supplied by a Standalone Direct Pumping Photovoltaic System. Sustainability, 10, 4203. https://doi.org/10.3390/su10114203

[71] Gad, H.E. (2009) Performance Prediction of a Proposed Photovoltaic Water Pumping System at South Sinai, Egypt Climate Conditions. 13th International Water 
Technology Conference, Egypt, January 2009, 739-752.

[72] Pande, P.C., Singh, A.K., Ansari, S., Vyas, S.K. and Dave, B.K. (2003) Design Development and Testing of a Solar PV Pump Based Drip System for Orchards. Renewable Energy, 28, 385-396. https://doi.org/10.1016/S0960-1481(02)00037-X

[73] Zhang, C., Campana, P.E., Yang, J. and Yan, J. (2017) Economic Performance of Photovoltaic Water Pumping Systems with Business Model Innovation in China. Energy Conversion and Management, 133, 498-510. https://doi.org/10.1016/j.enconman.2016.10.069

[74] Boutelhig, A., Bakelli, Y. and Arab, A.H. (2008) Study and Implementation of a Stand-Alone Photovoltaic Water Pumping System (PVPS) in Desert Region. Control, 95-100.

[75] Fiaschi, D., Graniglia, R. and Manfrida, G. (2005) Improving the Effectiveness of Solar Pumping Systems by Using Modular Centrifugal Pumps with Variable Rotational Speed. Solar Energy, 79, 234-244.

https://doi.org/10.1016/j.solener.2004.11.005

[76] Matamoros, D., Barzola, J. and Espinoza, M. (2015) Sizing Photovoltaic Irrigation Systems Using Meteorological Data. 8 th International Conference on Energy Planning, Energy Saving, Environmental Education, Roma, November 2015, 220-227.

[77] Mohammedi, A., Mezzai, N., Rekioua, D. and Rekioua, T. (2014) Impact of Shadow on the Performances of a Domestic Photovoltaic Pumping System Incorporating an MPPT Control: A Case Study in Bejaia, North Algeria. Energy Conversion and Management, 84, 20-29. https://doi.org/10.1016/j.enconman.2014.04.008

[78] Yahyaoui, I., Tadeo, F. and Segatto, M.V. (2017) Energy and Water Management for Drip-Irrigation of Tomatoes in a Semi-Arid District. Agricultural Water Management, 183, 4-15. https://doi.org/10.1016/j.agwat.2016.08.003

[79] Hamza, A.A. and Taha, A.Z. (1995) Performance of Submersible PV Solar Pumping. Water, 6, 491-495. https://doi.org/10.1016/0960-1481(95)00049-P

[80] Nasrin, R., Hasanuzzaman, M. and Rahim, N.A. (2017) Effect of High Irradiation on Photovoltaic Power and Energy. International Journal of Energy Research, 42, 1115-1131. https://doi.org/10.1002/er.3907

[81] Chandel, S.S., Nagaraju Naik, M. and Chandel, R. (2015) Review of Solar Photovoltaic Water Pumping System Technology for Irrigation and Community Drinking Water Supplies. Renewable \& Sustainable Energy Reviews, 49, 1084-1099. https://doi.org/10.1016/j.rser.2015.04.083

[82] Mittal, R., Sandhu, K.S. and Jain, D.K. (2013) An Overview of Some Important Issues Related to Wind Energy Conversion System (WECS). International Journal of Environmental Science and Development, 1, 351-363.

https://doi.org/10.7763/IJESD.2010.V1.69

[83] Feitosa, E.D.O., Albiero, D., Praciano, A.C., Macedo, D.X.S. and Chioderoli, C.A. (2014) Simulação Do Aproveitamento Da Energia Eólica Para Irrigação No Distrito De Irrigado Baixo-Acaraú-Ce. Revista Brasileira de Energias Renováveis, 3, 65-79. https://doi.org/10.5380/rber.v3i2.35560

[84] Kumbhar Sagar, S., Jagtap Dayanand, R., Momin Shaharukh, S. and Shinde, G.S. (2016) Review on Experimental Set Up of Drip Irrigation by Using Wind Energy. International Journal of Trend in Research and Development, 3, 205-208.

[85] Gosavi, V.R. (2015) Irrigation System and Water Lifting Using Wind Mill Energy. International Journal of Latest Trends in Engineering and Technology, 5, 208-212.

[86] Gilley, J.R., Martin, D.L. and Clark, N. (1985) Potential Use of Wind Power for Pumping Irrigation Water. Energy in Agriculture, 4, 133-146. 
https://doi.org/10.1016/0167-5826(85)90012-9

[87] Al-Jibouri, D.O.K.A. (2014) Feasibility of Using Wind Energy for Irrigation in Iraq. International Journal of Mechanical Engineering and Technology, 5, 62-72.

[88] Rehman, S. and Sahin, A.Z. (2012) Wind Power Utilization for Water Pumping Using Small Wind Turbines in Saudi Arabia: A Techno-Economical Review. Renewable \& Sustainable Energy Reviews, 16, 4470-4478. https://doi.org/10.1016/j.rser.2012.04.036

[89] Girma, M., Molina, M. and Assefa, A. (2015) Feasibility Study of a Wind Powered Water Pumping System for Rural Ethiopia. AIMS Energy, 3, 851-868. https://doi.org/10.3934/energy.2015.4.851

[90] Panda, R.K., Sarkar, T.K. and Bhattacharya, A.K. (1988) Cost Estimate of Chance-Constrained Windmill Irrigation System. Energy for Agriculture, 6, 311-324. https://doi.org/10.1016/0167-5826(88)90004-6

[91] Bragg, G.M. and Schmidt, W.L. (1979) Performance Matching and Optimization of Wind Powered Water Pumping Systems. Energy Conversion, 19, 33-39. https://doi.org/10.1016/0013-7480(79)90014-7

[92] Camocardi, P., Battaiotto, P. and Mantz, R. (2010) Autonomous BDFIG-Wind Generator with Torque and Pitch Control for Maximum Efficiency in a Water Pumping System. International Journal of Hydrogen Energy, 35, 5778-5785. https://doi.org/10.1016/j.ijhydene.2010.02.099

[93] Mohsen, M.S. and Akash, B.A. (1998) Potentials of Wind Energy Development for Water Pumping in Jordan. Renewable Energy, 14, 441-446. https://doi.org/10.1016/S0960-1481(98)00101-3

[94] Lara, D.D., Merino, G.G., Pavez, B.J. and Tapia, J.A. (2011) Efficiency Assessment of a Wind Pumping System. Energy Conversion and Management, 52, 795-803. https://doi.org/10.1016/j.enconman.2010.08.004

[95] Harries, M. (2002) Disseminating Wind Pumps in Rural Kenya-Meeting Rural Water Needs Using Locally Manufactured Wind Pumps. Energy Policy, 30, 1087-1094. https://doi.org/10.1016/S0301-4215(02)00060-5

[96] Velasco, M., Probst, O. and Acevedo, S. (2004) Theory of Wind-Electric Water Pumping. Renewable Energy, 29, 873-893.

https://doi.org/10.1016/j.renene.2003.10.001

[97] Purohit, P. and Kandpal, T.C. (2007) Techno-Economics of Biogas-Based Water Pumping in India: An Attempt to Internalize $\mathrm{CO}_{2}$ Emissions Mitigation and Other Economic Benefits. Renewable \& Sustainable Energy Reviews, 11, 1208-1226. https://doi.org/10.1016/j.rser.2005.09.003

[98] Gopal, C., Mohanraj, M., Chandramohan, P. and Chandrasekar, P. (2013) Renewable Energy Source Water Pumping Systems-A Literature Review. Renewable \& Sustainable Energy Reviews, 25, 351-370. https://doi.org/10.1016/j.rser.2013.04.012

[99] Puig-Arnavat, M., Bruno, J.C. and Coronas, A. (2010) Review and Analysis of Biomass Gasification Models. Renewable \& Sustainable Energy Reviews, 14, 2841-2851. https://doi.org/10.1016/j.rser.2010.07.030

[100] Mainali, B., Ahmed, H. and Silveira, S. (2018) Integrated Approach for Provision of Clean Energy and Water in Rural Bangladesh. Groundwater for Sustainable Development, 7, 239-249. https://doi.org/10.1016/j.gsd.2018.06.009

[101] Mehta, A., Srivastava, R., Yadav, V.K. and Singh, P. (2015) Automatic Drip Irrigation System Using Wind Energy. International Journal of Geology, Agriculture and Environmental Sciences, 3, 38-41. 
[102] Kumar, A. and Kandpal, T.C. (2007) Renewable Energy Technologies for Irrigation Water Pumping in India: A Preliminary Attempt towards Potential Estimation. Energy, 32, 861-870. https://doi.org/10.1016/j.energy.2006.05.004

[103] Aksoy, M.H., Kose, F. and Ozgoren, M. (2017) Experimental Investigation of a Water Pumping System Driven by Wind and Solar Energy for Irrigation Purpose. Annals of the Faculty of Engineering Hunedoara-International Journal of Engineering, 15, 219-224.

[104] Sba, K.M. (2018) Sizing of a Hybrid (Photovoltaic/Wind ) Pumping System-Based on Metaheuristic Optimization Methods. https://doi.org/10.1109/ICWEAA.2018.8605053

[105] Vick, B.D. and Neal, B.A. (2012) Analysis of Off-Grid Hybrid Wind Turbine/Solar PV Water Pumping Systems. Solar Energy, 86, 1197-1207. https://doi.org/10.1016/j.solener.2012.01.012

[106] Clark, R.N. and Vick, B.D. (2008) An ASABE Meeting Presentation Paper Number: 084176.

[107] Habib, M.A., Said, S.A.M., El-Hadidy, M.A. and Al-Zaharna, I. (1999) Optimization Procedure of a Hybrid Photovoltaic Wind Energy System. Energy, 24, 919-929. https://doi.org/10.1016/S0360-5442(99)00042-0

[108] Laamari, S., Zghal, W. and Kchaou, H. (2015) Optimization of Hybrid System (Wind-Solar Energy) for Pumping Water. International Journal of Engineering, Science and Technology, 7, 11-26. https://doi.org/10.4314/ijest.v7i2.2

[109] Alkarrami, F., Iqbal, T. and Pope, K. (2018) Modelling, Simulations and Operational Performance of a Stand-Alone Hybrid Wind/PV Energy System Supplying Induction Motor for Pumping Applications. International Journal of Engineering Systems Modelling and Simulation, 10, 12-25. https://doi.org/10.1504/IJESMS.2018.090237

[110] Pytlinski, J.T. (1978) Review Paper Solar Energy Installations for Pumping Irrigation Water. Solar Energy, 21, 255-262. https://doi.org/10.1016/0038-092X(78)90001-4

[111] Moonsri, P., Kunchornrat, J. and Namprakai, P. (2015) Hybrid Energy Thermal Water Pump for Producing Hot Water from a Shallow Well in Thailand. Journal of Energy Engineering, 142, Article ID: 04015023. https://doi.org/10.1061/(ASCE)EY.1943-7897.0000278

[112] Handayani, T.P., Hulukati, S.A., et al. (2018) Development of a Hybrid Power Supply Control Prototype for Solar-Powered Water Tank Pumping System. 2nd International Conference on Green Energy and Applications, Singapore, 88-92. https://doi.org/10.1109/ICGEA.2018.8356272

[113] Kumar, R. and Singh, B. (2016) Solar PV-Battery Based Hybrid Water Pumping System Using BLDC Motor Drive. https://doi.org/10.1109/ICPEICES.2016.7853662

[114] Shouman, E. and El Shenawy, E. (2016) Economics Analysis of Diesel and Solar Water Pumping with Case Study Water Pumping for Irrigation in Egypt. International Journal of Applied Engineering Research, 11, 950-954.

[115] Hammad, M. (1995) Photovoltaic, Wind and Diesel. A Cost Comparative Study of Water Pumping Options in Jordan. Energy Policy, 23, 723-726. https://doi.org/10.1016/0301-4215(95)00032-E

[116] Purohit, P. (2007) Financial Evaluation of Renewable Energy Technologies for Irrigation Water Pumping in India. Energy Policy, 35, 3134-3144. https://doi.org/10.1016/j.enpol.2006.11.013

[117] Powell, J.W., Welsh, J.M. and Farquharson, R. (2019) Investment Analysis of Solar 
Energy in a Hybrid Diesel Irrigation Pumping System in New South Wales, Australia. Journal of Cleaner Production, 224, 444-454.

https://doi.org/10.1016/j.jclepro.2019.03.071

[118] Mcsweeney, C., New, M. and Lizcano, G. (2015) Climate Change Profile: Mozambique. Climate Service Center, 7, 21.

[119] Security, F. (2018) National Irrigation Institute Smallholder Irrigated Agriculture and Market Access Project Resettlement Policy Framework (RPF).

[120] Baruah, P. and Coleman, B. (2019) Country Brief: Mozambique Off-Grid Solar Power in Mozambique: Opportunities for Universal Energy Access and Barriers to Private Sector Participation.

[121] Ministério da Energia (2014) Renewable Energy Atlas of Mozambique: Resources and Projects for Power Generation.

[122] Arthur, F., Nhumaio, G., Saide, A. and Cumbe, F. (2015) Solar Thermal Technology Roadmap for Mozambique. 1-27.

[123] Cuamba, B.C., Chenene, M.L., Mahumane, G., Quissico, D.Z., Lovseth, J. and O'Keefe, P. (2006) A Solar Energy Resources Assessment in Mozambique. Journal of Energy in Southern Africa, 17, 76-85.

https://doi.org/10.17159/2413-3051/2006/v17i4a3234

[124] Nijegorodov, N.I., Devan, K.R.S., Simao, H. and Mabbs, R. (2003) Comprehensive Study of Solar Conditions in Mozambique: The Effect of Trade Winds on Solar Components. Renewable Energy, 28, 1965-1983. https://doi.org/10.1016/S0960-1481(03)00038-7

[125] ACP-MEA and UNFCCC (2013) Emissions Reduction Profile of Mozambique.

[126] WWAP (2014) United Nations World Water Assessment Programme. The United Nations World Water Development Report 2014, Water and Energy, 1. 